\title{
A Roadmap for Systematically Identifying Opportunities in Ecosystems Using Scientific Publications Data
}

\author{
Behrooz Khademi, Hannele Lampela, Kosmas X. Smyrnios
}

\author{
I Opportunity identification process enables groups or individuals to screen a \\ large volume of ideas quickly and methodically. "
}

\author{
Dr. Rajiv Tandon (27.08.2015) \\ Serial Entrepreneur
}

\begin{abstract}
Opportunity identification is a continuous process in ecosystems. However, ambiguities and challenges associated with knowledge exploration and exploitation can retard opportunity recognition processes. This in turn may culminate in excessive expenditure of resources or loss of latent opportunities. The present study adopts an analytical approach and proposes a methodological roadmap that utilizes scientometric and text mining techniques. The roadmap uses data from Web of Science as input, and generates insights that support decision-making about resource saving, strategic planning, investment, and policymaking. Our roadmap extends methods used in studying ecosystems by combining existing and novel techniques in data analytics. Using Python and VOSViewer, we show an exemplary application of the new roadmap, framed in the context of the Nordic countries' renewable energy ecosystem.
\end{abstract}

\section{Introduction}

Managers and policy-makers are increasingly attracted to ecosystems. Actors constantly seek opportunities in knowledge (Jarvi, 2018; Almpanopoulou et al., 2019), innovation (Valkokari, 2015; Valkokari et al., 2017; Ketonen-Oksi \& Valkokari, 2019), and entrepreneurial (Autio et al., 2014; Stam, 2015; Thomas \& Autio, 2020) ecosystems. However, ambiguities and challenges associated with knowledge exploration (for example, lack of resources) (Jarvi et al., 2018; Almpanopoulou et al., 2019) and exploitation (for example, actor engagement, governance) (Clarysse et al., 2014; Jarvenpaa \& Välikangas, 2014, 2016) make opportunity recognition processes time-consuming, resourceintensive, and risky for ecosystem actors (Khademi, 2019). As no systematic way exists for mitigating the effects of these challenges, the present paper develops an analytics-driven roadmap for systematically identifying opportunities in spatially bounded ecosystems. The roadmap enables better decisionmaking with respect to strategic planning (collaboration, investment), promulgating innovation policy instruments, and saving resources (time and budget).
Since James Moore used the metaphor "ecosystem" (Moore, 1993) to show similarities between technologydriven networks and natural ecologies in terms of their "co-evolution" process and the symbiotic interrelationships required, thousands of scholarly contributions have extended our understanding of ecosystems. Scholars have identified various types of ecosystems such as business, innovation, knowledge, entrepreneurial, and service ecosystems (see Scaringella \& Radziwon, 2017; Valkokari, 2015 for distinctions between ecosystem types). This study mainly deals with knowledge, innovation, and entrepreneurial ecosystems.

It is no secret that opportunity identification is of paramount importance for organizations. In business word, opportunity recognition is usually known as seizing those initiatives that are directly translated into financial value. Examples of such business opportunities include new market segmentation and diversification of solution portfolio. Given today's competitive markets, businesses do not survive without exploiting new opportunities. 


\section{A Roadmap for Systematically Identifying Opportunities in Ecosystems Using Scientific Publications Data Behrooz Khademi, Hannele Lampela, Kosmas X. Smyrnios}

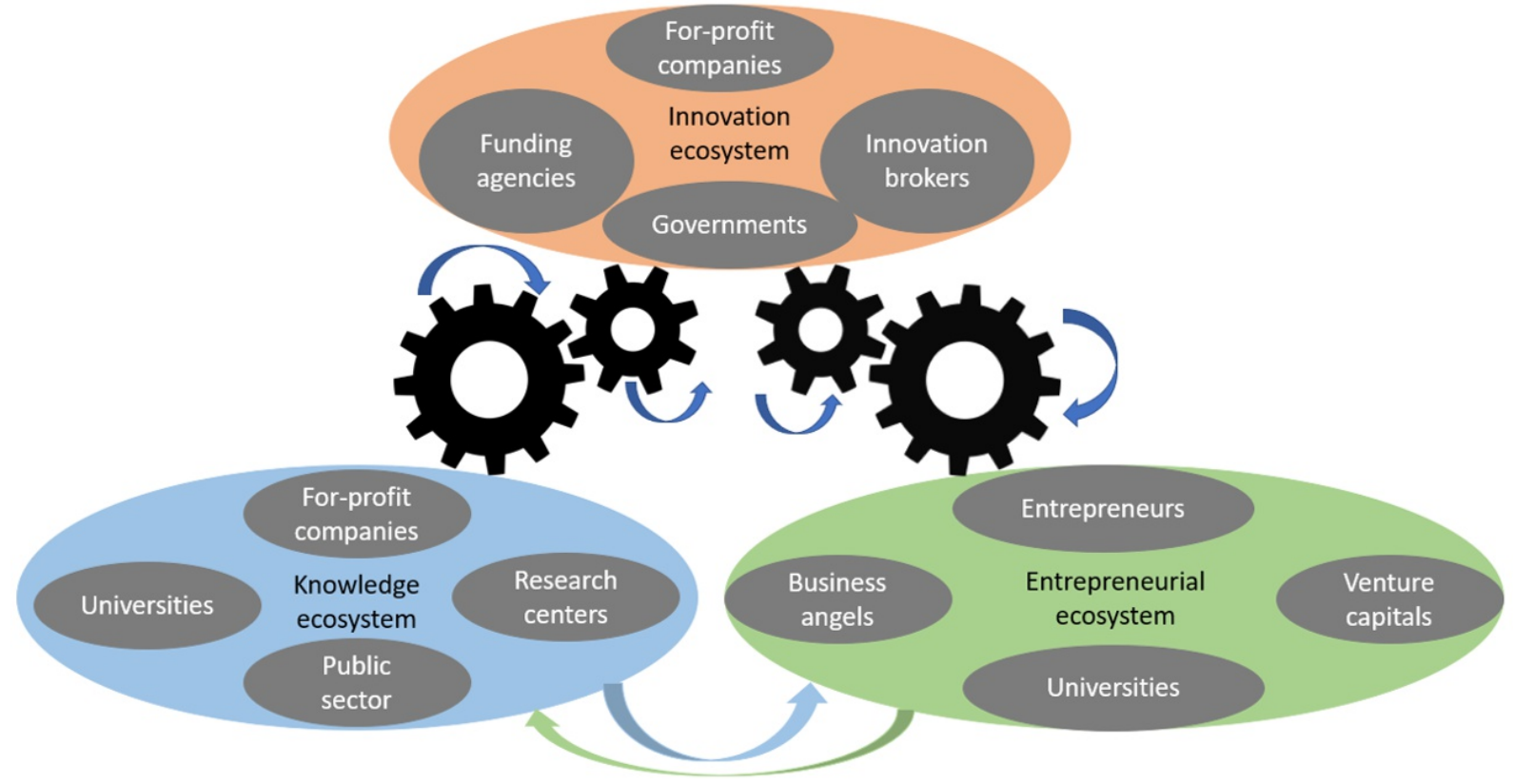

Figure 1. Interacting and integrating mechanisms between ecosystems

As it pertains to ecosystems, opportunity identification is critical for survival. Research shows that more than $85 \%$ of ecosystems fail at some point, with lack of adequate problems and opportunities being among the major failure reasons (Pidun et al., 2020). In ecosystems, opportunities are different from merely gaining shortterm financial value. Depending on the type of actor and ecosystem, actors seek different ways of contributing to the value co-creation process and coming up with final solutions. In knowledge ecosystems, actors (universities, research organizations, public sector, for-profit organizations) need to identify collaborative research partners, aim to win research grants, and seek external funding. Entrepreneurial ecosystem actors (tech startups, university spin-outs, investors) emerge around knowledge hubs to commercialize new knowledge and enhance their investment portfolio (Autio et al., 2014; Stam, 2015; Thomas \& Autio, 2020). To facilitate knowledge exploration and exploitation, innovation ecosystem actors (policy-makers, funding agencies) support new knowledge creation (for example, financing, providing co-working spaces) and engage actors through incentivization (Valkokari, 2015; Ketonen-Oksi \& Valkokari, 2019).

Figure 1 shows interacting and integrating mechanisms between the three types of ecosystems. Table 1 shows examples of existing ecosystems, actors, objectives, and opportunities for the three ecosystem types.
However, opportunity identification is a sophisticated process because of ambiguities and challenges associated with knowledge exploration, knowledge exploitation, and integration mechanisms. In knowledge ecosystems, actors face issues such as resourcing, absence of consensus involving knowledge domains and participating actors (Jarvi et al., 2018), lack of prior knowledge of other actors (Lindkvist, 2005), and policy and cognitive constraints (Almpanopoulou et al., 2019). Governments face challenges when integrating knowledge exploration and exploitation with respect to selecting areas of excellence in research for the region, making valid decisions to provide research grants, and organizing for collaborative research partnerships, which requires facilities and governance (Valkokari, 2015; Ketonen-Oksi \& Valkokari, 2019). Industry players and private-sector investors should decide whether and to what extent investing in knowledge exploration and exploitation is profitable. Tech start-ups should find ways to persuade public and private sectors to fund their ideas or prototypes. Otherwise, potential opportunities may remain latent, or their untimely exploration can pose noticeable expenses to actors.

Previously, scholars have studied these challenges mainly using inductive approaches. They have suggested practices such as open innovation, selective and interactive revealing and governing, collective action and orchestration, and knowledge formalization through 


\section{A Roadmap for Systematically Identifying Opportunities in Ecosystems Using Scientific Publications Data Behrooz Khademi, Hannele Lampela, Kosmas X. Smyrnios}

Table 1. Ecosystem structures, objectives, opportunities and examples

\begin{tabular}{|c|c|c|c|c|c|}
\hline $\begin{array}{c}\text { Type of } \\
\text { ecosystem }\end{array}$ & References & $\begin{array}{c}\text { Participating } \\
\text { actors }\end{array}$ & Empirical examples & Objectives & Opportunities \\
\hline $\begin{array}{l}\text { Knowledge } \\
\text { ecosystem }\end{array}$ & $\begin{array}{l}\text { - Almpanopoulou } \\
\text { et al. (2019) } \\
\text { - Jarvi et al. } \\
\text { (2018) }\end{array}$ & $\begin{array}{l}\text { - Universities } \\
\text { - Research } \\
\text { centers } \\
\text { - public sector } \\
\text { - For-profit } \\
\text { organizations }\end{array}$ & $\begin{array}{l}\text { - Australian } \\
\text { Research Centers } \\
\text { - Region of Flanders } \\
\text { (Belgium) } \\
\text { - Strategic Centers } \\
\text { for Science, } \\
\text { Technology, and } \\
\text { Innovation } \\
\text { (Finland) }\end{array}$ & $\begin{array}{l}\text { - Co-create new } \\
\text { knowledge } \\
\text { - Gain scientific } \\
\text { reputation } \\
\text { - Recruit talented } \\
\text { researchers }\end{array}$ & $\begin{array}{l}\text { - Identify } \\
\text { collaborative } \\
\text { research partners } \\
\text { - Win research } \\
\text { grants and awards } \\
\text { from funding } \\
\text { agencies } \\
\text { - Achieve external } \\
\text { funding from } \\
\text { private sector and } \\
\text { technology firms }\end{array}$ \\
\hline $\begin{array}{l}\text { Innovation } \\
\text { ecosystem }\end{array}$ & $\begin{array}{l}\text { - Valkokari } \\
\text { (2015) } \\
\text { - Valkokari et al. } \\
(2017) \\
\text { - Ketonen-Oksi } \\
\text { and Valkokari } \\
(2019)\end{array}$ & $\begin{array}{l}\text { - Governments } \\
\text { - Funding } \\
\text { agencies } \\
\text { - Innovation } \\
\text { brokers } \\
\text { - companies }\end{array}$ & $\begin{array}{l}\text { - Mobile and } \\
\text { telecommunication } \\
\text { ecosystems } \\
\text { (Deutsche } \\
\text { Telekom) } \\
\text { - Smart city } \\
\text { innovation } \\
\text { ecosystems (e.g., } \\
\text { London, } \\
\text { Stockholm) } \\
\text { - Federal } \\
\text { government-led } \\
\text { innovation } \\
\text { ecosystems (e.g., } \\
\text { Australia, } \\
\text { Singapore) }\end{array}$ & $\begin{array}{l}\text { - Integrate } \\
\text { knowledge } \\
\text { exploration and } \\
\text { exploitation } \\
\text { mechanisms } \\
\text { - Incentivize actors } \\
\text { for technology } \\
\text { commercialization } \\
\text { - Provide space for } \\
\text { co-innovation and } \\
\text { knowledge co- } \\
\text { creation }\end{array}$ & $\begin{array}{l}\text { - Discern areas of } \\
\text { research } \\
\text { excellence } \\
\text { - Identify potential } \\
\text { collaborative } \\
\text { research } \\
\text { opportunities } \\
\text { - Fund the most } \\
\text { popular and } \\
\text { impactful research } \\
\text { in knowledge } \\
\text { hubs } \\
\text { - Regulatory } \\
\text { instruments for } \\
\text { private sector } \\
\text { investment in } \\
\text { targeted research } \\
\text { areas }\end{array}$ \\
\hline $\begin{array}{l}\text { Entrepren- } \\
\text { eurial } \\
\text { ecosystem }\end{array}$ & $\begin{array}{l}\text { - } \text { Thomas and } \\
\text { Autio (2020) } \\
\text { - Stam (2015) } \\
\text { - Autio et al. } \\
\text { (2014) }\end{array}$ & $\begin{array}{l}\text { - Entrepreneurs } \\
\text { - Universities } \\
\text { - Business } \\
\text { - } \text { angels } \\
\text { - Venture } \\
\text { capitalists }\end{array}$ & $\begin{array}{l}\text { - Silicon Valley } \\
\text { - Calgary's energy } \\
\text { ecosystem } \\
\text { - Melbourne's med- } \\
\text { tech ecosystem }\end{array}$ & $\begin{array}{l}\text { - Expand } \\
\text { entrepreneurial } \\
\text { activity } \\
\text { - Increase regional } \\
\text { GDP } \\
\text { - Attract investors }\end{array}$ & $\begin{array}{l}\text { - Identify promising } \\
\text { areas of research } \\
\text { for technology } \\
\text { commercialization } \\
\text { - Make informed } \\
\text { decisions for } \\
\text { investment } \\
\text { portfolio analysis } \\
\end{array}$ \\
\hline
\end{tabular}

virtual collaboration (Rohrbeck et al., 2009; Perry et al., 2010; Pellinen et al., 2012; Alexy et al., 2013; Jarvenpaa \& Välikangas, 2014, 2016; Jarvi et al., 2018) in specific contexts. Yet, no systematic method for accelerating opportunity recognition in ecosystems currently prevails.

Within this content, the objective of the present study is to bridge the above-mentioned research gap by adopting an analytical approach and proposing a roadmap for systematic opportunity identification in ecosystems. Specifically, we aim to develop a roadmap that inputs data from Web of Science (WoS), utilizing scientometric and text mining techniques, and enables actors of different ecosystem types to systematically identify opportunities. To show how the roadmap operates in practice, we demonstrate its application using bulk scientific data collected on renewable energy from the Nordic region (Finland, Sweden, Norway, Denmark, and Iceland). The main research question navigating our paper is as follows: How can opportunity recognition processes in ecosystems be accelerated and enhanced systematically and parsimoniously?

We begin by delineating the details of the proposed roadmap. Next, we describe the methods used for an example application of the roadmap. Subsequently, we present findings of the exemplar. Finally, we discuss contributions of the study, and conclude by outlining limitations as well as potential future research avenues. 


\section{A Roadmap for Systematically Identifying Opportunities in Ecosystems Using Scientific Publications Data Behrooz Khademi, Hannele Lampela, Kosmas X. Smyrnios}

\section{A Roadmap for Systematic Opportunity Identification in Ecosystems}

The roadmap enables actors of a region to systematically identify opportunities in a specific knowledge domain using data derived from Web of Science (WoS). It can be applied to different settings in terms of domain, region, and timeframe. Figure 2 illustrates the ten sequential steps used when implementing the roadmap, which we elaborate on below.

\subsection{Boundary Definition}

The first step is to make decisions regarding the knowledge domain (for example, renewable energy), regional boundaries (for example, the Nordic region), and time span for analysing bibliographic data (for example, 1999-2019). Such decisions depend on the project in hand and the value creation rationale for actors.

\subsection{Question Formulation}

Step 2 involves formulating questions that can be answered by implementing the roadmap. A nonexhaustive list of the example questions that can be formulated and answered using this roadmap is shown in Table 2.

\subsection{Journal Selection}

The third step is to select highly ranked journals in the ecosystem's field. In so doing, one can use Scimago Journal \& Country Rank (SJR) or national ranking systems. SJR is a well-known source, which assigns each academic journal to a "quartile" $(\mathrm{Q})$, with Q1s as the most respected journals.

\subsection{Database Selection}

The fourth step is to select a database for data extraction. We recommend selecting WoS when using this roadmap because in comparison with SCOPUS it provides a longer time span and wider coverage of citations, more comprehensive metadata for funding agencies, and harmonized names for research organizations and universities.

\subsection{Sampling and Information Retrieval}

The fifth step is to prepare a thorough list of keywords and terms to search for the relevant publication records. Sampling strategies for scientific publications are implemented with the continuous involvement of field experts to optimize percentages of recall and precision.

\subsection{Data Extraction}

The roadmap's inputs consist of two types of data: WoS

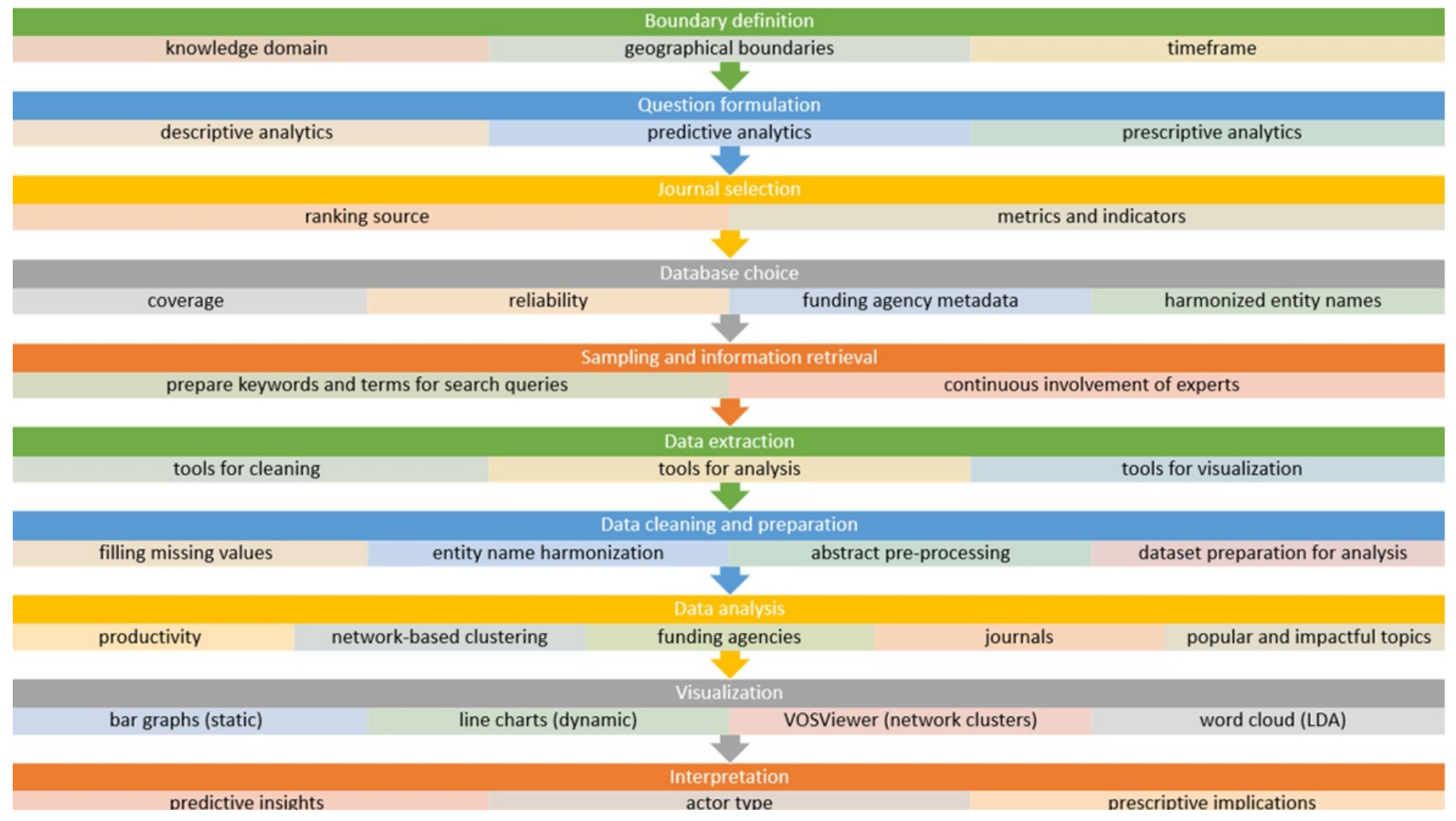

Figure 2. Methodological roadmap for systematic opportunity identification in ecosystems 


\section{A Roadmap for Systematically Identifying Opportunities in Ecosystems Using Scientific Publications Data Behrooz Khademi, Hannele Lampela, Kosmas X. Smyrnios}

Table 2. Example questions to be answered by using the roadmap

\begin{tabular}{|c|c|c|c|c|}
\hline Stage & $\begin{array}{l}\text { Analytics } \\
\text { type }\end{array}$ & Prerequisites & Question & $\begin{array}{l}\text { Unit of } \\
\text { analysis in } \\
\text { WoS data }\end{array}$ \\
\hline \multirow{11}{*}{1} & \multirow{11}{*}{ Descriptive } & \multirow{11}{*}{ Data from WoS } & $\begin{array}{l}\text { Which research departments have been most } \\
\text { productive? }\end{array}$ & \multirow{4}{*}{$\begin{array}{l}\text { Research } \\
\text { departments }\end{array}$} \\
\hline & & & $\begin{array}{l}\text { Which departments have been most productive over } \\
\text { time? }\end{array}$ & \\
\hline & & & $\begin{array}{l}\text { What are the major clusters of research departments } \\
\text { based on research similarity? }\end{array}$ & \\
\hline & & & $\begin{array}{l}\text { What are the major clusters of research departments } \\
\text { based on collaborative research? }\end{array}$ & \\
\hline & & & $\begin{array}{l}\text { Which funding agencies have been listed as financial } \\
\text { sponsors most frequently? }\end{array}$ & \multirow{2}{*}{$\begin{array}{l}\text { Funding } \\
\text { agencies }\end{array}$} \\
\hline & & & $\begin{array}{l}\text { Which funding agencies have been listed as financial } \\
\text { sponsors most frequently over time? }\end{array}$ & \\
\hline & & & Which journals have been of interest the most? & \multirow[b]{2}{*}{ Journals } \\
\hline & & & $\begin{array}{l}\text { Which journals have been of interest the most over } \\
\text { time? }\end{array}$ & \\
\hline & & & $\begin{array}{l}\text { What are the main research themes of interest for the } \\
\text { scholars? }\end{array}$ & \multirow{3}{*}{ Abstracts } \\
\hline & & & $\begin{array}{l}\text { How have the themes of interest transitioned in recent } \\
\text { years? }\end{array}$ & \\
\hline & & & $\begin{array}{l}\text { What research themes have been more impactful in } \\
\text { recent years? }\end{array}$ & \\
\hline \multirow{6}{*}{2} & \multirow{6}{*}{ Predictive } & \multirow{6}{*}{ Descriptive results } & $\begin{array}{l}\text { How can the productivity of the most productive } \\
\text { departments be anticipated? }\end{array}$ & \multirow{2}{*}{$\begin{array}{l}\text { Research } \\
\text { departments }\end{array}$} \\
\hline & & & $\begin{array}{l}\text { Which possible collaboration opportunities between } \\
\text { research departments can be systematically identified? }\end{array}$ & \\
\hline & & & $\begin{array}{l}\text { Which funding agencies will financially support the } \\
\text { scholarly research in future? }\end{array}$ & $\begin{array}{l}\text { Funding } \\
\text { agencies }\end{array}$ \\
\hline & & & $\begin{array}{l}\text { Which journals will publish contributions from the } \\
\text { scholars of the region the most? }\end{array}$ & Journals \\
\hline & & & $\begin{array}{l}\text { Which research themes will be more popular in the } \\
\text { region? }\end{array}$ & \multirow{2}{*}{ Abstracts } \\
\hline & & & $\begin{array}{l}\text { Which research themes will be more impactful in the } \\
\text { region? }\end{array}$ & \\
\hline \multirow{9}{*}{3} & \multirow{9}{*}{ Prescriptive } & \multirow{9}{*}{$\begin{array}{l}\text { Descriptive and } \\
\text { predictive results }\end{array}$} & $\begin{array}{l}\text { How can novice and experienced research scholars } \\
\text { improve their productivity and find grants for new } \\
\text { projects? }\end{array}$ & \multirow{9}{*}{$\begin{array}{l}\text { All four units } \\
\text { above }\end{array}$} \\
\hline & & & $\begin{array}{l}\text { How can academics benefit from the analyses in course } \\
\text { design and development? }\end{array}$ & \\
\hline & & & $\begin{array}{l}\text { How can the department managers improve } \\
\text { department productivity? }\end{array}$ & \\
\hline & & & $\begin{array}{l}\text { In what ways can academic entrepreneurs benefit from } \\
\text { the analyses for commercialization of potential ideas? }\end{array}$ & \\
\hline & & & $\begin{array}{l}\text { How can journal editors organize special issues based } \\
\text { on specific problems of the region? }\end{array}$ & \\
\hline & & & $\begin{array}{l}\text { How can funding agency managers benefit from the } \\
\text { analyses in organizing new funding programmes? }\end{array}$ & \\
\hline & & & $\begin{array}{l}\text { How can industry managers identify university- } \\
\text { industry collaboration opportunities? }\end{array}$ & \\
\hline & & & $\begin{array}{l}\text { How can industry managers and investors benefit from } \\
\text { the analysis for investment? }\end{array}$ & \\
\hline & & & $\begin{array}{l}\text { In what ways policymakers can benefit from the } \\
\text { analysis to promulgate policies? }\end{array}$ & \\
\hline
\end{tabular}




\section{A Roadmap for Systematically Identifying Opportunities in Ecosystems Using Scientific Publications Data Behrooz Khademi, Hannele Lampela, Kosmas X. Smyrnios}

Reports and bibliographic records. The Reports consist of descriptive statistics from the sample, as well as citation reports on the sample. It is necessary when extracting bibliographic data to consider in advance the tools employed for data munging, analysis, and visualization. Since employing programming languages increases the accuracy of analysis, we recommend extracting tabular datasets (for example, tab-delimited text files) to maximize accuracy.

\subsection{Data Wrangling}

Downloaded data usually require "wrangling" prior to analysis. The main tasks are filling in missing values, entity (funding agencies and journals) name harmonization, pre-processing abstracts, and preparing new datasets for data analysis. Separate datasets are generated for each unit of analysis with a column related to the year of publication for each record. In addition to publication year, funding agency dataset should include a column related to country names, while abstracts should include the number of publication citations (see 2.8).

\subsection{Data Analysis}

Except for network clustering, data are analyzed both statically and dynamically. In static measurement, the entire timeframe $T$ is taken into account, whereas in dynamic analyses, $T$ is divided by the number of years.

\section{Productivity}

Static productivity of research departments is measured via four metrics: the $h$-index, share of departments in the total number of records, share of departments from all citations received by the sample, and percentage of selfcitations for each department. Dynamic analysis of the number of publications and citations provides rigorous insights regarding business productivity over time.

\section{Clustering}

Departments are clustered based on research similarity and collaboration using bibliographic coupling and coauthorship analysis, respectively. We recommend using VOSViewer (van Eck \& Waltman, 2009), as it provides specific features and configurations for clustering and visualization.

\section{Analysis of funding agencies}

The absolute number of high-quality publications in a specific domain positively correlates with the size of research grants (Gralka et al., 2019). Accordingly, higher number of papers published in prestigious journals by grantees in a specific knowledge domain positively correlates with larger sizes of grants allocated by funding agencies in that knowledge domain. As a novel measure, we rank funding organizations statically based on their share in the total pair number of paper-sponsor records. A dynamic analysis calculates the yearly frequency of support for each agency.

\section{Journal analysis}

Journals in the sample are analyzed statically via their publishing share. The share of each journal is calculated via the frequency of published outputs in that journal divided by the total number of records in the sample. Dynamic analyses calculate the yearly number of papers published by each journal.

\section{Topic modelling}

For a static analysis, latent Dirichlet allocation (LDA) is employed for theme exploration by analyzing abstracts over the timeframe $T$. Dynamic analyses of abstracts are divided into two types of analysis: popularity and impact. For the former analysis, theme transitions are based on the yearly frequency of terms used in the abstracts. The results indicate themes that have been more popular over time in the region, where emphasis on recent years can be helpful for forecasting. For the latter analysis, the same method is employed by using only a slice of data that contains the most cited papers for each year. The analysis output shows the most impactful research themes conducted in the region on a yearly basis.

\subsection{Visualization}

To report the results in an informative way, roadmap users should employ different types of visuals for each type of analysis. For static representation of analyses involving productivity, funding agencies, and journals, bar charts are often the best options. To visualize outputs related to dynamic analyses, line charts can be employed. Network visualizations provided by VOSViewer demonstrate clusters of research departments based on similarity and collaboration. Word clouds report the output of static topic models.

\subsection{Interpretation}

At this stage, the outputs of all descriptive and predictive insights are used collectively to discover prescriptive implications for different actors and ecosystems. Table 3 is a non-exhaustive list of implications depending on the types of ecosystem and actor. 


\section{A Roadmap for Systematically Identifying Opportunities in Ecosystems Using Scientific Publications Data Behrooz Khademi, Hannele Lampela, Kosmas X. Smyrnios}

Table 3. Prescriptive implications of the roadmap

\begin{tabular}{|c|c|c|c|}
\hline No & $\begin{array}{l}\text { Ecosystem } \\
\text { type }\end{array}$ & Actor type & Prescriptive implications \\
\hline \multirow{5}{*}{1} & \multirow{5}{*}{$\begin{array}{l}\text { Knowledge } \\
\text { ecosystems }\end{array}$} & $\begin{array}{l}\text { Novice and experienced research } \\
\text { scholars }\end{array}$ & $\begin{array}{l}\text { - identify collaborators in academic organizations for future } \\
\text { publications } \\
\text { - evaluate PhD and post-doc applicants based on their } \\
\text { proposal impact and promise } \\
\text { - identify funding agencies with possible sources of financial } \\
\text { sponsorship to fund future research projects } \\
\text { - draft new projects based on promising research themes } \\
\text { - modernize course curriculum based on popular and } \\
\text { impactful research themes in the region }\end{array}$ \\
\hline & & $\mathrm{PhD}$ and post-doc applicants & $\begin{array}{l}\text { - identify productive academics with possible sources of } \\
\text { funding for their proposed research } \\
\text { - develop proposals with higher chance of approval (in } \\
\text { collaboration with academics) based on popular and } \\
\text { impactful research themes } \\
\text { - predict possible outlets (journals) when drafting proposals } \\
\text { - explore relevant funding agencies for possible grant } \\
\text { applications }\end{array}$ \\
\hline & & Research department managers & $\begin{array}{l}\text { - strategic planning for increasing productivity } \\
\text { - identify research partners based on productivity and } \\
\text { research similarity } \\
\text { - draft new grant applications based on promising research } \\
\text { themes } \\
\text { - informed recruitment decision-making when evaluating } \\
\text { research job applicants }\end{array}$ \\
\hline & & Industry managers & $\begin{array}{l}\text { - identify potential university-industry collaboration } \\
\text { opportunities based on organization productivity and } \\
\text { research similarity } \\
\text { - identify academic allies for core technology development } \\
\text { - identify academic allies for development of complementary } \\
\text { technologies } \\
\text { - systematic investment in basic research } \\
\text { - commercialization of the explored knowledge } \\
\text { focal actor strategy planning and business ecosystem } \\
\text { genesis or expansion }\end{array}$ \\
\hline & & Journal editors and managers & $\begin{array}{l}\text { - organize special issues (or joint special issues) for practical } \\
\text { problem-solving in the region }\end{array}$ \\
\hline \multirow[b]{2}{*}{2} & \multirow[b]{2}{*}{$\begin{array}{l}\text { Innovation } \\
\text { ecosystems }\end{array}$} & Grant allocation managers & $\begin{array}{l}\text { - informed evaluation of grant allocation process based on } \\
\text { (individual and organizational) productivity and the } \\
\text { promise of submitted proposals } \\
\text { - identify partners for collaborative funding programmes in } \\
\text { the areas with practical, financial and societal value }\end{array}$ \\
\hline & & Federal and state-level governments & $\begin{array}{l}\text { - monitor productivity of academic organizations and } \\
\text { individuals } \\
\text { - supportive and regulatory policies for improving } \\
\text { productivity of academic organizations } \\
\text { - supportive and regulatory policies for directing private } \\
\text { sector investments towards popular and impactful areas of } \\
\text { research } \\
\text { - systematic job creation for researchers based on promising } \\
\text { research themes } \\
\text { - Incentivizing systematic research partnerships } \\
\text { - coordinating knowledge, innovation, entrepreneurial and } \\
\text { business ecosystems }\end{array}$ \\
\hline \multirow{3}{*}{3} & \multirow{3}{*}{$\begin{array}{l}\text { Entrepreneurial } \\
\text { ecosystems }\end{array}$} & $\begin{array}{l}\text { Academic entrepreneurs and } \\
\text { university spin-outs }\end{array}$ & $\begin{array}{l}\text { - encourage students to focus on promising research ideas } \\
\text { - identify sources of financial sponsorship for developing } \\
\text { prototypes and patents }\end{array}$ \\
\hline & & Tech start-ups & $\begin{array}{l}\text { - identify sources of financial sponsorship for developing } \\
\text { prototypes and patents } \\
\text { - access to information regarding most relevant research } \\
\text { themes for better drafting of research proposals or grant } \\
\text { applications }\end{array}$ \\
\hline & & Investors & $\begin{array}{l}\text { - informed decision-making for investment in basic research } \\
\text { - informed decision-making for investment in university- } \\
\text { industry partnerships } \\
\text { - enhanced decisions when investing in start-ups and spin- } \\
\text { outs }\end{array}$ \\
\hline
\end{tabular}




\section{A Roadmap for Systematically Identifying Opportunities in Ecosystems Using Scientific Publications Data Behrooz Khademi, Hannele Lampela, Kosmas X. Smyrnios}

\section{Example}

In this section, we discuss the relevance of the Nordic renewable energy ecosystem and delineate multiple methods used to test the roadmap. Note that this example does not refer to any specific existing ecosystem within the Nordic region. Rather, we show how a hypothetical application of the proposed roadmap can support decision-making for those who may would like to consider forming a new ecosystem, expanding an existing one, or joining an existing one.

\subsection{Relevance}

The Nordic renewable energy ecosystem supplies a relevant exemplar for our roadmap application for three reasons. First, renewable energy is well-known for heterogeneity of actors and taking a collective approach to creating new knowledge (Dougherty \& Dunne, 2011). Second, Nordic countries have consistently ranked among the top 15 countries worldwide in terms of percentage of gross domestic product (GDP) spent on research and development for the last two decades (OECD, 2018), which has enabled the extraction of rich bibliographic data resources. Third, an emphasis is placed by Nordic countries on the need for identifying opportunities through empirical scientific energy research within the Nordic region (NEA).

\subsection{Data Extraction and Sampling}

SJR was the most suitable journal ranking system for this study with its category that designates "Renewable Energy, Sustainability and Environment" (SCImago). This made it reliable to filter our search of scholarly journals relevant to renewable energy. The choice of journals was limited to Q1 and Q2 journals to ensure a sample of the most scholarly research (79 journals). WoS has a subscription for 74 out of the 79 identified sources (94\%), where all Q1 journals were covered.

Data extraction and sampling processes were conducted in April 2020. We used the keyword "energ*" in the search field "Topic" in WoS to ensure extraction of a sample related to renewable energy. Our search strategy filtered the results to those papers published in English, with at least one author affiliated to a Nordic organization. We also limited the results to the timeframe $T 1=(1999-2019)$ both because of the upward trend in funding greenhouse gas emissions reduction research (Overland \& Sovacool, 2020), and a rise in renewable energy research outputs (Ziegler, 2011) since 1999. It is noteworthy that data from 2020 were excluded due to being incomplete. The final sample included $N=$ 6,148 journal articles. Yearly number of publications, citations, self-citations and $h$-indices for the top 15 research departments were extracted from WoS Reports.

\section{Sampling Process}

Identify Q1 and Q2 journals

Field-based search in WoS:

Include only identified

journals in 'Publication Name'

$N=133,075$

search field

AND

Include the Keyword "energ*"

in the 'Topic' search field

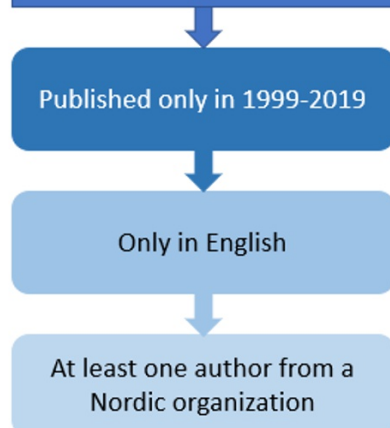

$N=119,800$

$N=119,794$

$N_{\text {final }}=6,148$

Figure 3. Step-by-step sampling process 


\section{A Roadmap for Systematically Identifying Opportunities in Ecosystems Using Scientific Publications Data Behrooz Khademi, Hannele Lampela, Kosmas X. Smyrnios}

Table 4. Scientific productivity of Nordic renewable energy research departments

\begin{tabular}{|c|c|c|c|c|c|c|c|c|}
\hline Rank & $\begin{array}{l}\text { Department of } \\
\text { renewable energy } \\
\text { research }\end{array}$ & $\begin{array}{l}- \\
\text { index }\end{array}$ & $\begin{array}{l}\text { Number } \\
\text { of } \\
\text { records }\end{array}$ & $\begin{array}{l}\text { Share in } \\
\text { number } \\
\text { of } \\
\text { records } \\
(\%) \\
\end{array}$ & $\begin{array}{l}\text { Number } \\
\text { of } \\
\text { citations }\end{array}$ & $\begin{array}{l}\text { Share in } \\
\text { total } \\
\text { number of } \\
\text { citations } \\
(\%) \\
\end{array}$ & $\begin{array}{l}\text { Number of } \\
\text { self-cited } \\
\text { papers }\end{array}$ & $\begin{array}{l}\text { Percentage } \\
\text { of self- } \\
\text { citations }\end{array}$ \\
\hline $\mathbf{1}$ & $\begin{array}{l}\text { Technical University } \\
\text { of Denmark (DTU) }\end{array}$ & 86 & 805 & 13.1 & 30,212 & 22.08 & 616 & 2.04 \\
\hline 2 & $\begin{array}{l}\text { KTH Royal Institute } \\
\text { of Technology }\end{array}$ & 56 & 576 & 9.37 & 13,592 & 9.93 & 496 & 3.65 \\
\hline 3 & Uppsala University & 55 & 351 & 5.71 & 12,380 & 9.05 & 276 & 2.23 \\
\hline 4 & Aalborg University & 54 & 498 & 8.1 & 12,015 & 8.78 & 344 & 2.86 \\
\hline 5 & Lund University & 52 & 328 & 5.34 & 9,286 & 6.79 & 265 & 2.85 \\
\hline 6 & $\begin{array}{l}\text { Norwegian } \\
\text { University of } \\
\text { Science and } \\
\text { Technology (NTNU) }\end{array}$ & 51 & 405 & 6.59 & 10,396 & 7.60 & 220 & 2.12 \\
\hline 7 & $\begin{array}{l}\text { Chalmers University } \\
\text { of Technology }\end{array}$ & 51 & 377 & 6.13 & 11,743 & 8.58 & 286 & 2.44 \\
\hline 8 & $\begin{array}{l}\text { Linkoping } \\
\text { University }\end{array}$ & 48 & 238 & 3.87 & 6,396 & 4.67 & 278 & 4.35 \\
\hline 9 & Aarhus University & 46 & 270 & 4.39 & 6,987 & 5.11 & 249 & 3.56 \\
\hline 10 & $\begin{array}{l}\text { Swedish University } \\
\text { of Agricultural } \\
\text { Sciences }\end{array}$ & 44 & 206 & 3.35 & 5,278 & 3.86 & 233 & 4.41 \\
\hline 11 & Aalto University & 42 & 381 & 6.2 & 6,846 & 5.00 & 313 & 4.57 \\
\hline 12 & SINTEF & 31 & 167 & 2.72 & 3,624 & 2.65 & 80 & 2.21 \\
\hline 13 & $\begin{array}{l}\text { VTT Technical } \\
\text { Research Center } \\
\text { Finland }\end{array}$ & 31 & 140 & 2.28 & 3,165 & 2.31 & 59 & 1.86 \\
\hline 14 & $\begin{array}{l}\text { Lappeenranta } \\
\text { University of } \\
\text { Technology (LUT) }\end{array}$ & 29 & 136 & 2.21 & 2,284 & 1.67 & 194 & 8.49 \\
\hline 15 & $\begin{array}{l}\text { University of } \\
\text { Southern Denmark }\end{array}$ & 27 & 103 & 1.68 & 2,630 & 1.92 & 30 & 1.14 \\
\hline
\end{tabular}

Figure 3 illustrates the step-by-step sampling process.

\subsection{Data Wrangling, Analysis and Visualization}

We filled the missing values in the column containing publication years. Next, we created harmonized entity names using Python string manipulation techniques, regular expressions, a Fuzzywuzzy library, and human intervention. Also, we generated a VOSViewer thesaurus file containing disambiguated names of research departments. Subsequently, new datasets were formed according to the roadmap instructions. Finally, we conducted abstract pre-processing and topic modelling using the Python Spacy and genism LDA libraries, respectively.
We took into account two timeframes $T 1=(1999-2019)$ and $T 2=(2014-2019)$ for the static and dynamic analyses, respectively. Selecting the last six years (T2) for a dynamic analysis provided the proper line plots for forecasting. We utilized Python (Matplotlib and Word Cloud modules) and VOSViwer to present the results.

\section{Results}

Here we present the results of the roadmap application based on the types of analysis described in the roadmap.

\subsection{Productivity}

As we filtered the data to find renewable energy research 


\section{A Roadmap for Systematically Identifying Opportunities in Ecosystems Using Scientific Publications Data Behrooz Khademi, Hannele Lampela, Kosmas X. Smyrnios}

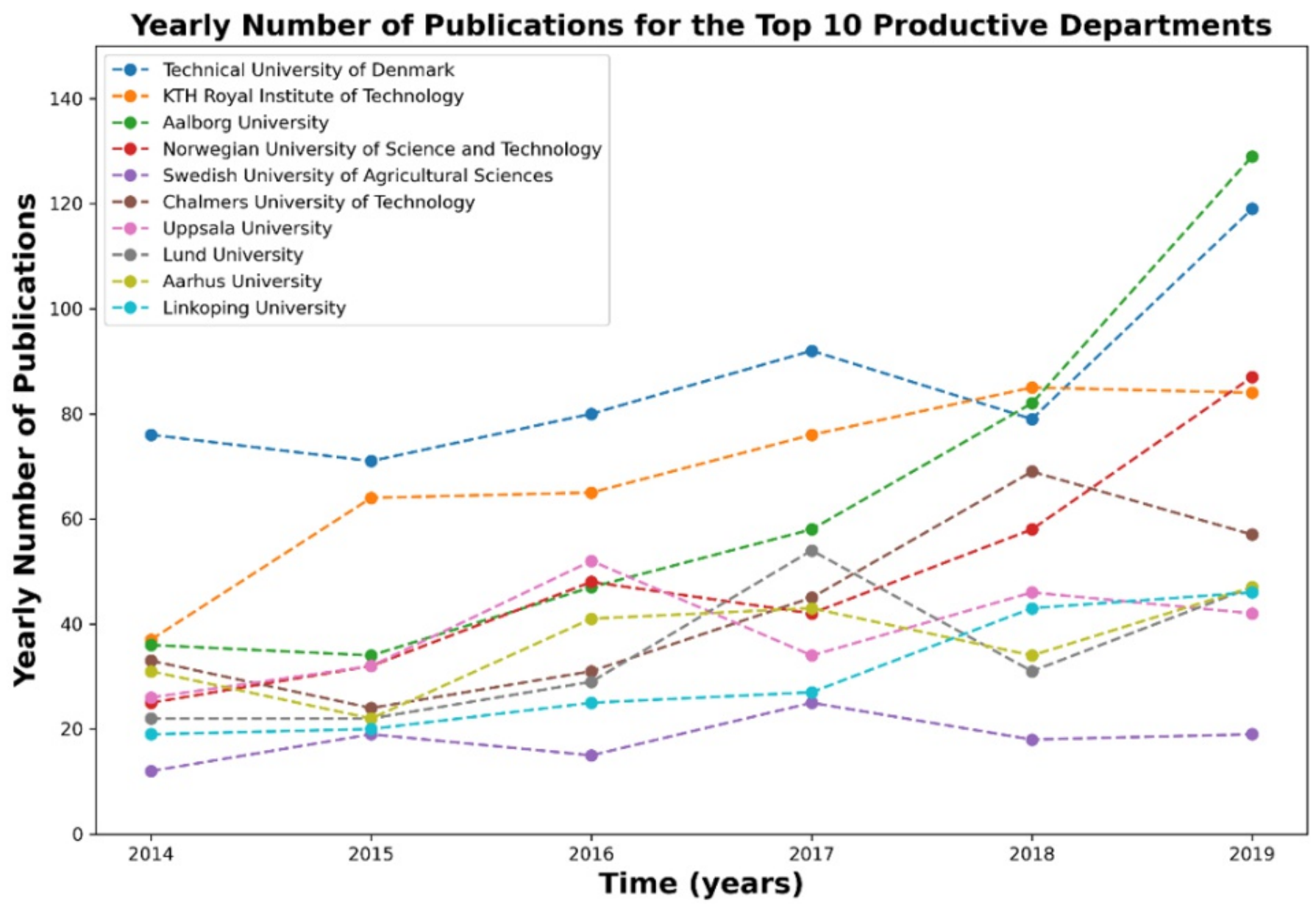

Figure 4. Yearly number of publications for the top 10 productive departments

only, we did not compare productivity of entire organizations. Rather, we limited the comparison to departmental research about renewable energy. We thus used the term "department" to refer to renewable energy research groups (or units) in universities and research organizations.

Table 4 illustrates the top 15 productive Nordic departments in renewable energy research. Arguably, the renewable energy department at DTU ranks first with an h-index of 86. Departments for KTH and Uppsala University are the laggers. Besides the renewable energy department for NTNU, all top 10 departments belong to Sweden and Denmark. Taking the number and share of papers associated with renewable energy departments of Uppsala University and Lund University into account, their number and share of citations were relatively high. In general, the percentage of self-citation is relatively low for all departments.
Figure 4 depicts the yearly number of publications by each of the top 10 most productive departments in $T 2$. The yearly number of publications has been growing for most departments. The records for DTU's renewable energy department have fluctuated over time, then spiked in 2019. Among the top 10 departments, the slope for yearly number of publications for Aalborg University, $\mathrm{KTH}$, and NTNU is steep. The renewable energy department for Aalborg University shows the fastest recent publication rise, overtaking DTU's renewable energy department in 2018. The number of published papers by the renewable energy departments of Uppsala University, Lund University, and Aarhus University increased significantly in 2016-2017, but have since fluctuated.

Figure 5 shows yearly number of citations received by the top 10 most productive departments in T2. Except for the renewable energy department at the Swedish University of Agricultural Sciences, the numbers for all 


\section{A Roadmap for Systematically Identifying Opportunities in Ecosystems Using Scientific Publications Data Behrooz Khademi, Hannele Lampela, Kosmas X. Smyrnios}

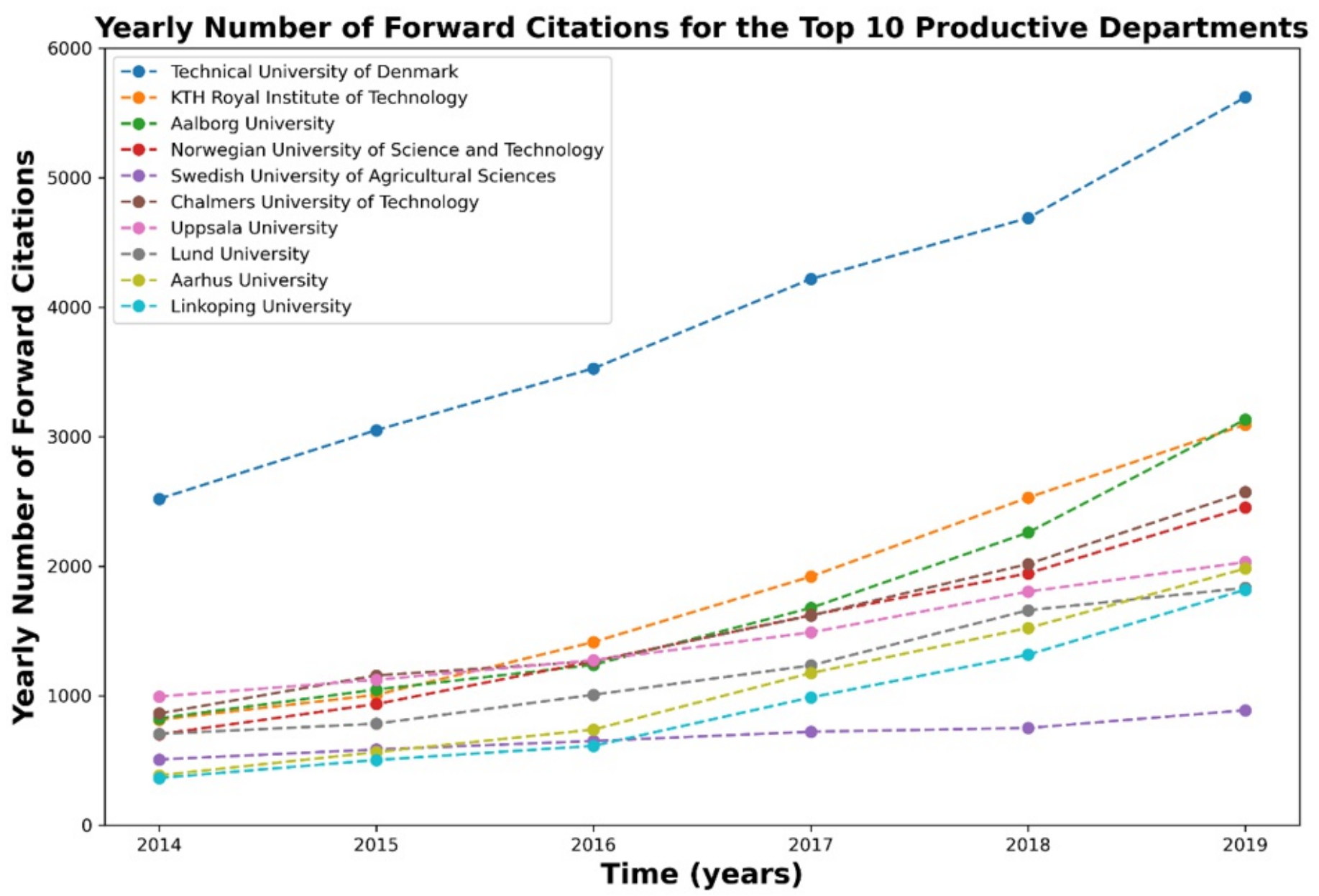

Figure 5. Yearly number of forward citations for the top 10 productive departments

top 10 departments have surged in recent years. The yearly citation slope for DTU's renewable energy department is constant and with a dominant position, while the renewable energy departments for KTH, Aalborg University, Chalmers, and NTNU have been noticeably impactful. Uppsala University, Lund University, and Aarhus University show a significant research impact in renewable energy.

We anticipate that DTU will keep its dominant position in renewable energy research. However, the competition will be tighter among DTU and other institutions. KTH, Aalborg University, and NTNU have been more productive than DTU in renewable energy research within T2. We expect that the renewable energy departments for these institutions will aim to publish more frequently. Renewable energy research affiliated to KTH, Aalborg University, Chalmers and NTNU has been noticeably impactful and we predict that the corresponding departments in these organizations will continue to be increasingly influential in the Nordic scientific community for renewable energy. Renewable energy departments for Uppsala University, Lund University, and Aarhus University have recently shown a significant rise in number of publications and research impact, and their productivity is also expected to rise.

\subsection{Clustering}

Figures 6 and 7 depict the clusters based on collaboration and research similarity, respectively. Nordic renewable energy research departments tend to collaborate with their parochial counterparts. Finnish and Norwegian departments have been particularly less interested in cross-border collaboration. Swedish and Danish departments, in contrast, have collaborated with renewable energy departments from the EU, USA, and China. International collaboration also contributes to higher levels of productivity.

Although international collaboration between Nordic 


\section{A Roadmap for Systematically Identifying Opportunities in Ecosystems Using} Scientific Publications Data Behrooz Khademi, Hannele Lampela, Kosmas X. Smyrnios

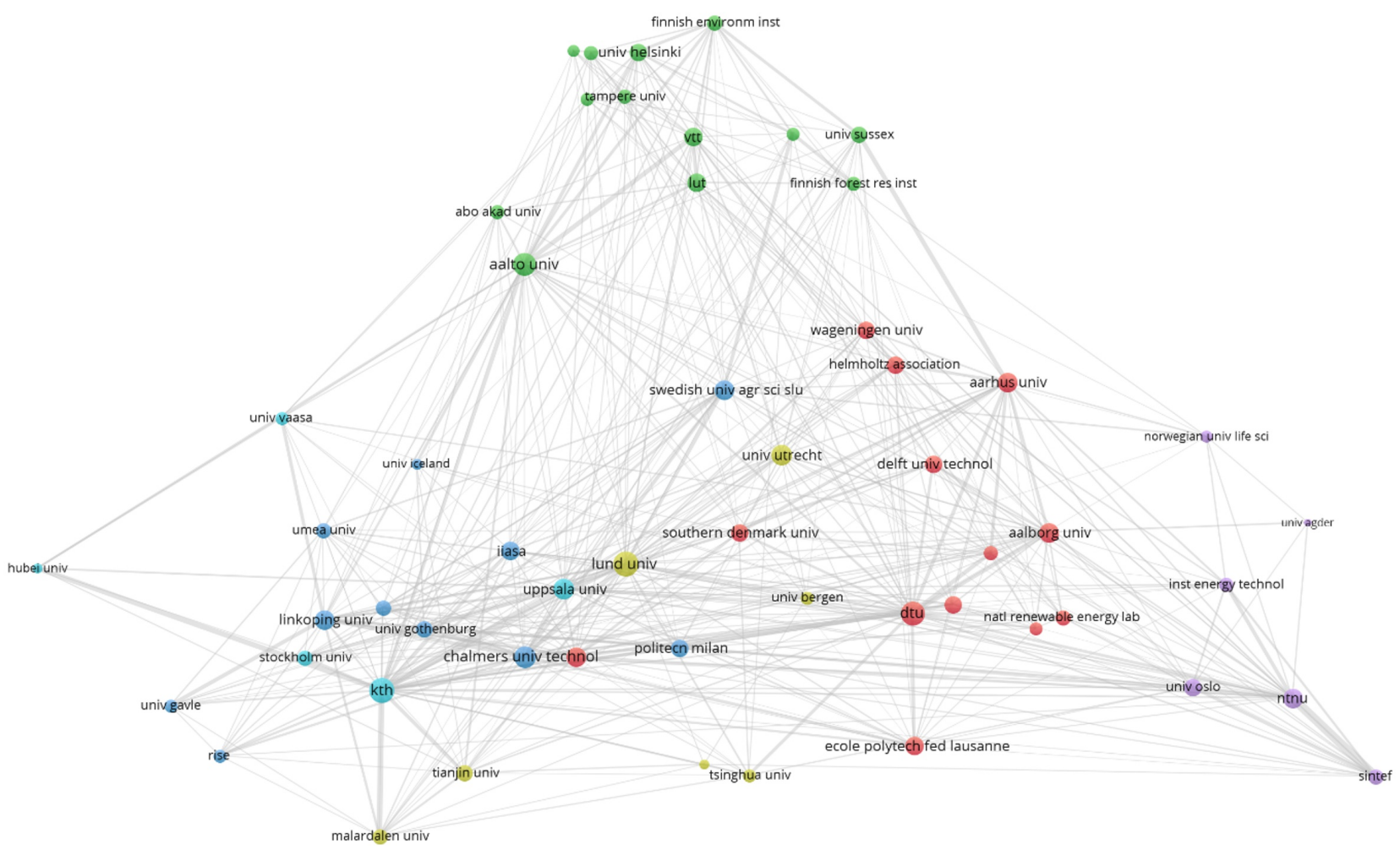

Figure 6. Clusters of Nordic renewable energy departments based on collaborative behaviour

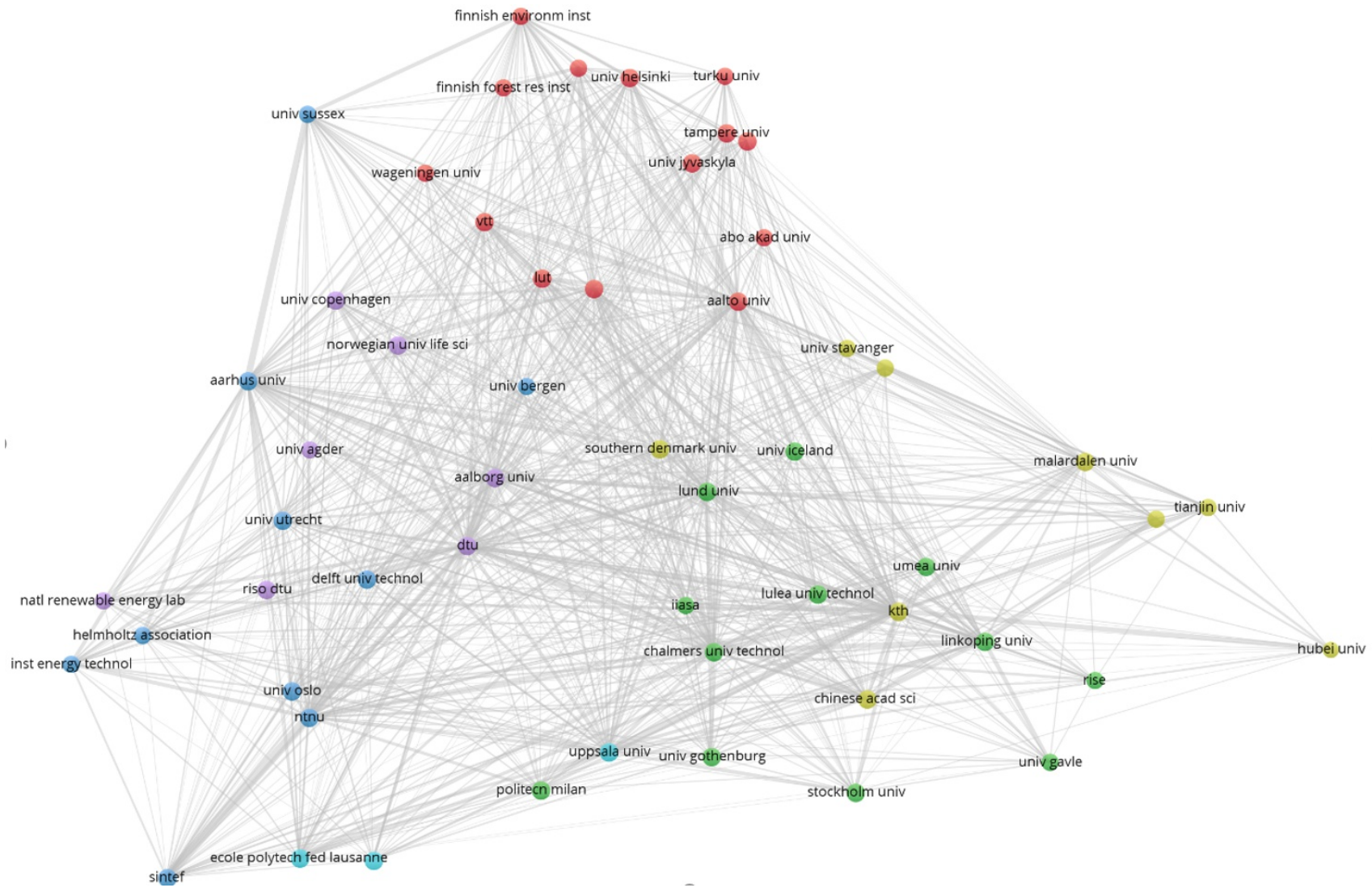

Figure 7. Clusters of Nordic renewable energy departments based on research similarity 


\section{A Roadmap for Systematically Identifying Opportunities in Ecosystems Using Scientific Publications Data Behrooz Khademi, Hannele Lampela, Kosmas X. Smyrnios}

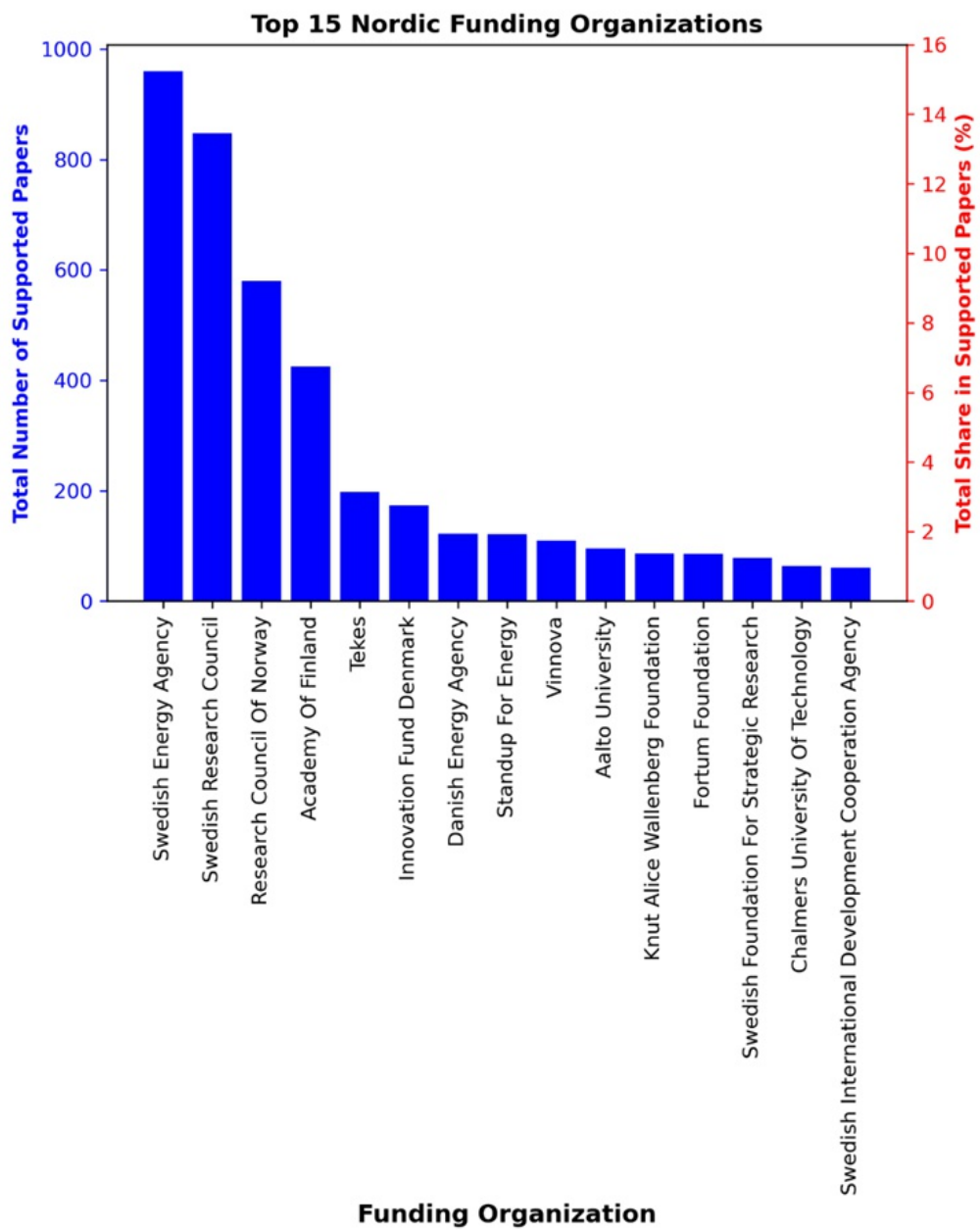

Figure 8. Share of the top 15 Nordic funding agencies in supported publications

countries is not so common, their research outputs nevertheless share similarities (see Figure 7). For example, the clusters of Danish and Norwegian departments that were formed based on their research similarity (see the dark blue and purple clusters in Figure 7) are less distinct in comparison with their clusters based on their research collaboration propensity (see the purple and red clusters in Figure 6). The European organizations are more spread out between clusters in Figure 7 , showing similarities in renewable energy research across European countries.

Research similarities cannot be solely justified by collaboration and potential remains open to form new partnerships. For example, while the similarity of research between Wageningen University \& Research and VTT is high, no previous record of collaboration exists between these institutions in renewable energy research. The same pattern applies to the departments at the Helmholtz Association and Institute for Energy
Technology. Note that although our analyses may assist with systematic identification of possible collaboration opportunities, actual partnership formation between institutions depends on other factors, such as availability of resources.

\subsection{Analysis of Funding Agencies}

Figure 8 shows the top 15 Nordic funding organizations with the biggest shares in the total number of funded research outputs. The Swedish Energy Agency and Swedish Research Council with $15.5 \%$ and $14 \%$ shares rank first and second, while the Research Council of Norway (11\%) and Academy of Finland (8\%) rank third and fourth. Business Finland (Tekes) occupies the fifth position with a share of $3.2 \%$. Among other funding agencies, no single organization has a share larger than $3 \%$. Figure 9 depicts the share of Nordic countries in funding renewable energy research.

Figure 10 depicts the yearly number of papers sponsored 
A Roadmap for Systematically Identifying Opportunities in Ecosystems Using Scientific Publications Data Behrooz Khademi, Hannele Lampela, Kosmas X. Smyrnios

\section{Share of Nordic Countries in Financially Supported Research Outputs}

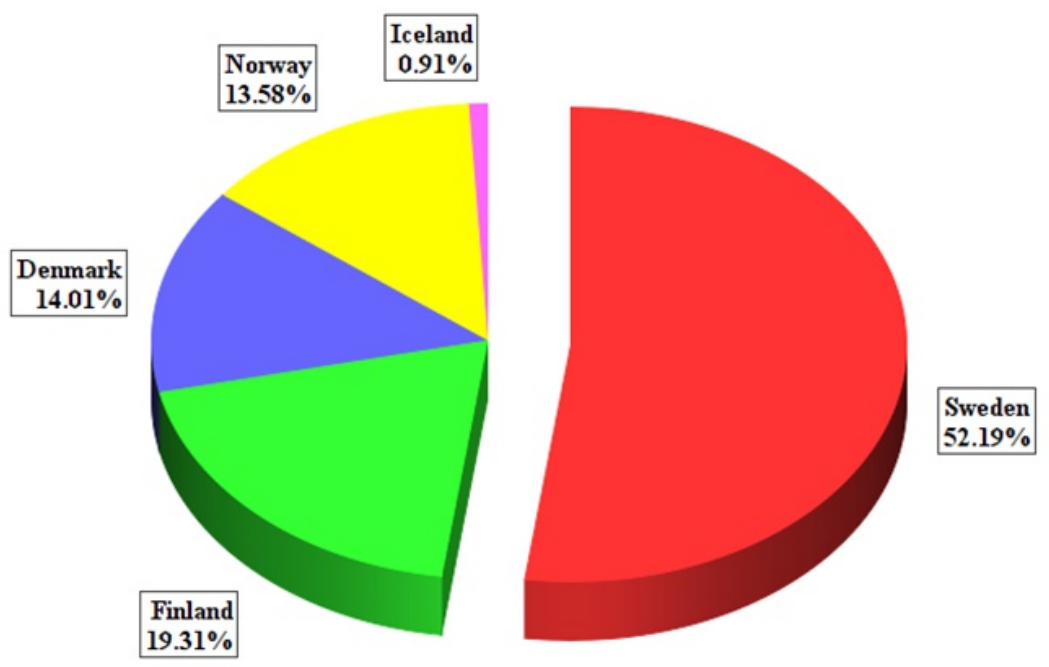

Figure 9. Share of Nordic countries in supported publications

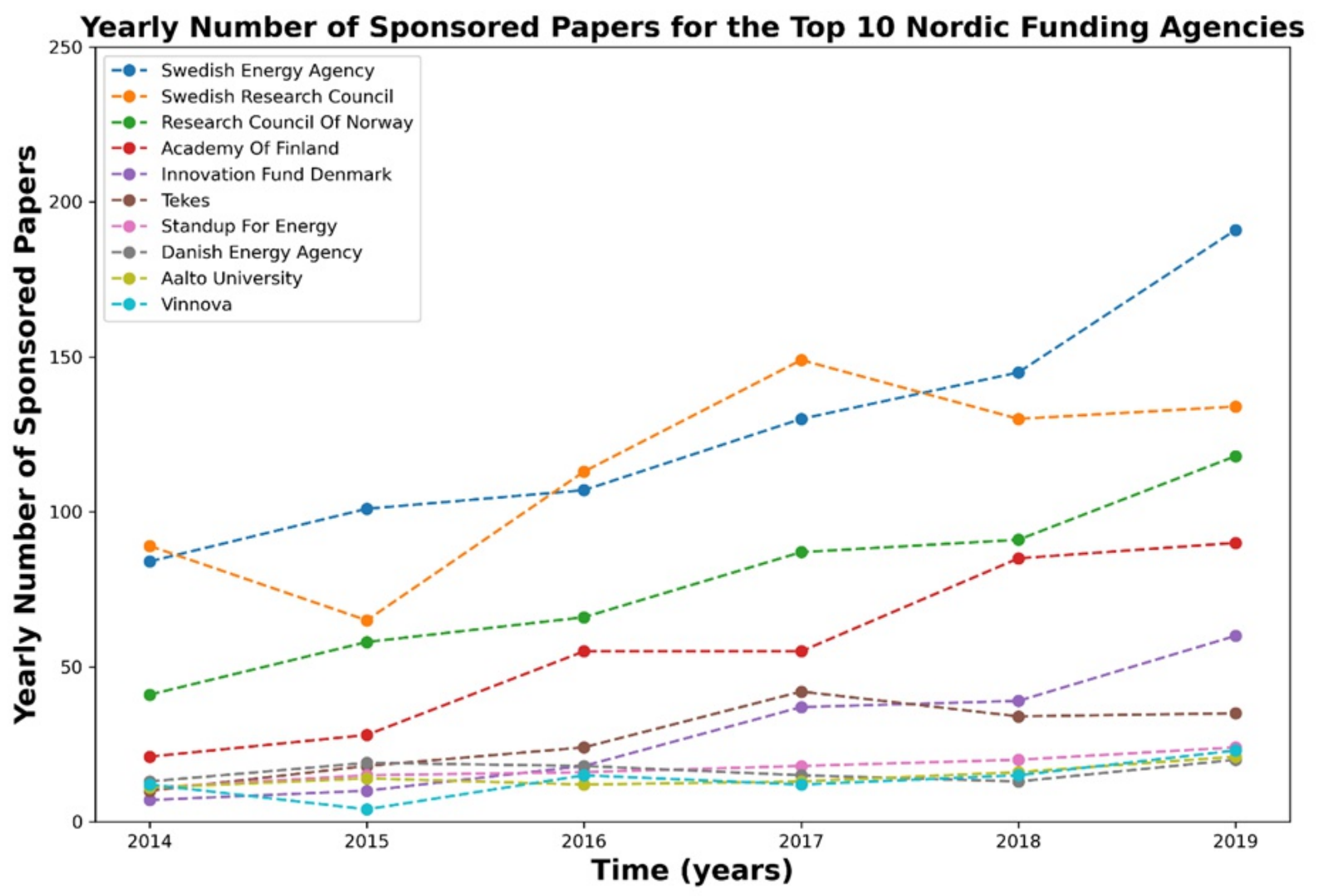

Figure 10. Yearly number of sponsored papers for the top 10 Nordic funding agencies 


\section{A Roadmap for Systematically Identifying Opportunities in Ecosystems Using Scientific Publications Data Behrooz Khademi, Hannele Lampela, Kosmas X. Smyrnios}

by the top 10 Nordic funding agencies over T2. The yearly number of publications sponsored by the Swedish Energy Agency, Swedish Research Council, Research Council of Norway, and the Academy of Finland has surged. In addition, the yearly number of outputs supported by Business Finland and Innovation Fund Denmark has increased noticeably.

Our analyses suggest that the Swedish Energy Agency will continue to be the top Nordic funding agency in support of renewable energy research. The slope for the number of publications authored by grantees of the Research Council of Norway was steeper than that the Swedish Research Council grantees over T2, hence it is likely that the Research Council of Norway will rank second. In a similar vein, the Academy of Finland is considered as a potential rival for the Swedish Research
Council. The grantees of Innovation Fund Denmark published a higher number of papers than Business Finland in 2018-2019, and thus, Innovation Fund Denmark might overtake Business Finland. The Swedish Energy Agency, Research Council of Norway, Swedish Research Council, and the Academy of Finland will continue to sponsor renewable energy research more noticeably than other Nordic funding agencies.

\subsection{Journal Analysis}

Table 5 lists the top 20 journals with publications authored by scholars based in the Nordic region in $T 1$.

Figure 11 shows the yearly number of papers published by each of the top 10 journals in $T 2$. The number of papers published in Energies and the Journal of Cleaner Production has risen dramatically, whereas the number

Table 5. Top 20 journals of interest for Nordic organizations in renewable energy research

\begin{tabular}{|c|c|c|c|}
\hline Rank & Source Name & Frequency & Share (\%) \\
\hline 1 & International Journal of Hydrogen Energy & 780 & 13 \\
\hline 2 & Journal of Cleaner Production & 625 & 10 \\
\hline 3 & Energies & 573 & 9 \\
\hline 4 & Biomass \& Bioenergy & 384 & 6 \\
\hline 5 & Renewable \& Sustainable Energy Reviews & 381 & 6 \\
\hline 6 & Renewable Energy & 349 & 6 \\
\hline 7 & Energy Conversion and Management & 237 & 4 \\
\hline 8 & Sustainability & 236 & 4 \\
\hline 9 & Energy Research \& Social Science & 168 & 3 \\
\hline 10 & Bioresource Technology & 163 & 3 \\
\hline 11 & Solar Energy & 163 & 3 \\
\hline 12 & Wind Energy & 162 & 3 \\
\hline 13 & Journal of Power Sources & 161 & 3 \\
\hline 14 & Journal of Materials Chemistry $A$ & 156 & 3 \\
\hline 15 & Journal of The Electrochemical Society & 127 & 2 \\
\hline 16 & Solar Energy Materials \& Solar Cells & 112 & 2 \\
\hline 17 & International Journal of Energy Research & 99 & 2 \\
\hline 18 & Nano Energy & 91 & 1 \\
\hline 19 & Environmental Research Letters & 85 & 1 \\
\hline 20 & Energy \& Environmental Science & 81 & 1 \\
\hline
\end{tabular}




\section{A Roadmap for Systematically Identifying Opportunities in Ecosystems Using Scientific Publications Data Behrooz Khademi, Hannele Lampela, Kosmas X. Smyrnios}

of papers published in the International Journal of Hydrogen Energy has fluctuated over time, with the closing number in 2019 even lower than the initial number in 2014. Among other journals, scholars affiliated with the Nordic region have published more frequently in Renewable \& Sustainable Energy Reviews as well as Sustainability. Recently, scholars based in the Nordic region have been less enthusiastic with publishing in Biomass \& Bioenergy, and Renewable Energy.

A significant rise in the number of papers published in Energies and the Journal of Cleaner Production can thus be expected. Scholars affiliated with Nordic organizations are most likely to publish in Renewable \& Sustainable Energy Reviews and Sustainability, but less often in Biomass \& Bioenergy and Renewable Energy.

\subsection{Topic Modelling}

Figure 12 depicts the topic coherence (using c_v algorithm) for topics in the range $K=(2-50)$. Although coherence was maximum in $K=14$ (0.53 after hyperparameter tuning), we found the number of clusters inadequate. The topics did not encompass socio-techno-economic issues, energy storage and distribution, and renewable energy sources. Therefore, we repeated the analysis until we reached a conclusion that at $K=42$, the above issues were addressed sufficiently (coherence of 0.48 after hyperparameter tuning). The word cloud in Figure 13 displays the output of the LDA model, while Table 6 details our subjective clustering of the word cloud.

Dynamic analyses show that the research intensity in all five clusters has risen over time. Growth of interest towards socio-techno-economic issues has been the highest, followed by energy production, storage and distribution. Among socio-techno-economic research themes, energy policy, energy efficiency, market demand, scenario analyses (supply cost and price), sustainable transition, supply chain and logistics, environmental impact, and lifecycle assessment are the

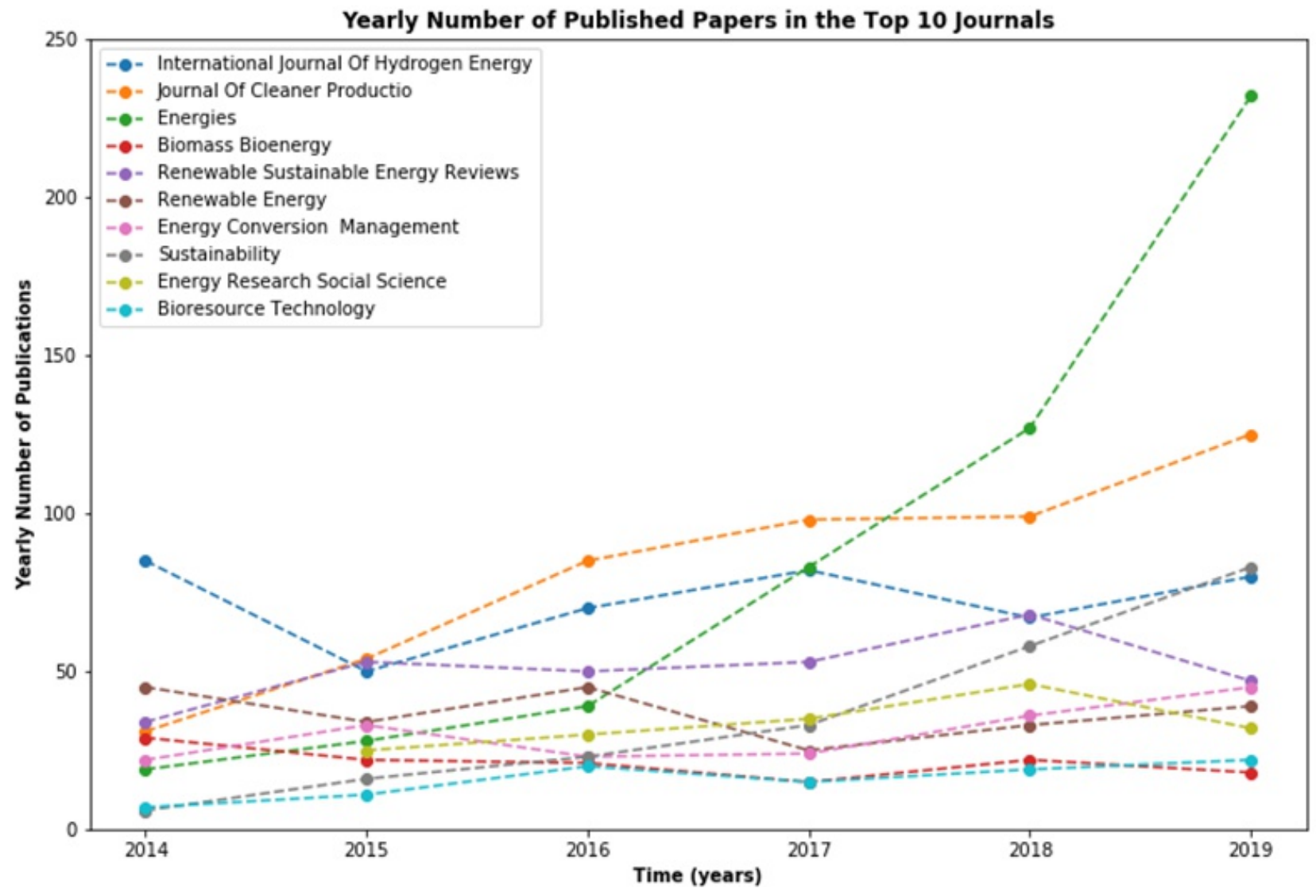

Figure 11. Yearly number of papers published in the top 10 journals 


\section{A Roadmap for Systematically Identifying Opportunities in Ecosystems Using Scientific Publications Data Behrooz Khademi, Hannele Lampela, Kosmas X. Smyrnios}

most popular. Biomass and solar energy research received noticeable attention in 2018-2019. In contrast, despite a surge in 2019, wind energy research has been less popular. The rising popularity of bioenergy, biogas, biofuel, wave, geothermal, and hydropower sources is also evident. Hydrogen energy storage and power grids research has gained traction conspicuously since 2014. In energy consumption research, household consumption as well as applications of renewable energy sources in buildings, electric vehicles, and public lighting have been of the most interest.

Dynamic analyses also show energy cost modelling is among the most impactful themes. In a similar vein, solar and biomass energy themes have consistently been among the most cited topics. The impact of hydrogen energy storage research has fluctuated, eventually reaching a peak in 2019. Energy efficiency research has been among the most cited themes since 2017. Despite a surge in 2016-2017, research on environmental issues has not been among the most impactful themes.

\section{Discussion and Conclusion}

Our study addressed the theoretical debate on challenges in knowledge exploration (Lindkvist, 2005; Jarvenpaa \& Välikangas, 2014, 2016; Jarvi et al., 2018; Almpanopoulou et al., 2019) and exploitation (Clarysse et al., 2014) in ecosystems. In contrast to the previous inductive approaches (Rohrbeck et al., 2009; Perry et al., 2010; Pellinen et al., 2012; Alexy et al., 2013; Jarvenpaa \& Välikangas, 2014, 2016; Jarvi et al., 2018), our proposed analytical approach resulted in a systematic methodology that saves resources (response to the research question) thanks to the availability of scientific publications data.

\subsection{Managerial and Policy Implications}

In this paper, we showed a hypothetical exemplary application of the proposed roadmap used on the Nordic renewable energy ecosystem. Below, we show examples of implications for actors of each ecosystem type in the Nordic region. Note that when applying the roadmap to other contexts (with respect to knowledge domain and region) the prescriptive implications will be similar (see Table 3 ).

As it pertains to the knowledge ecosystem in Nordic renewable energy research, research scholars and department managers can use insights from the roadmap for strategic planning, identifying research partners for prospective projects, drafting publications and grant applications collaboratively, and recruiting new cohorts. C-suite industry managers can evaluate the productivity of their departments and academic allies for collaborative research, as well as discern research areas

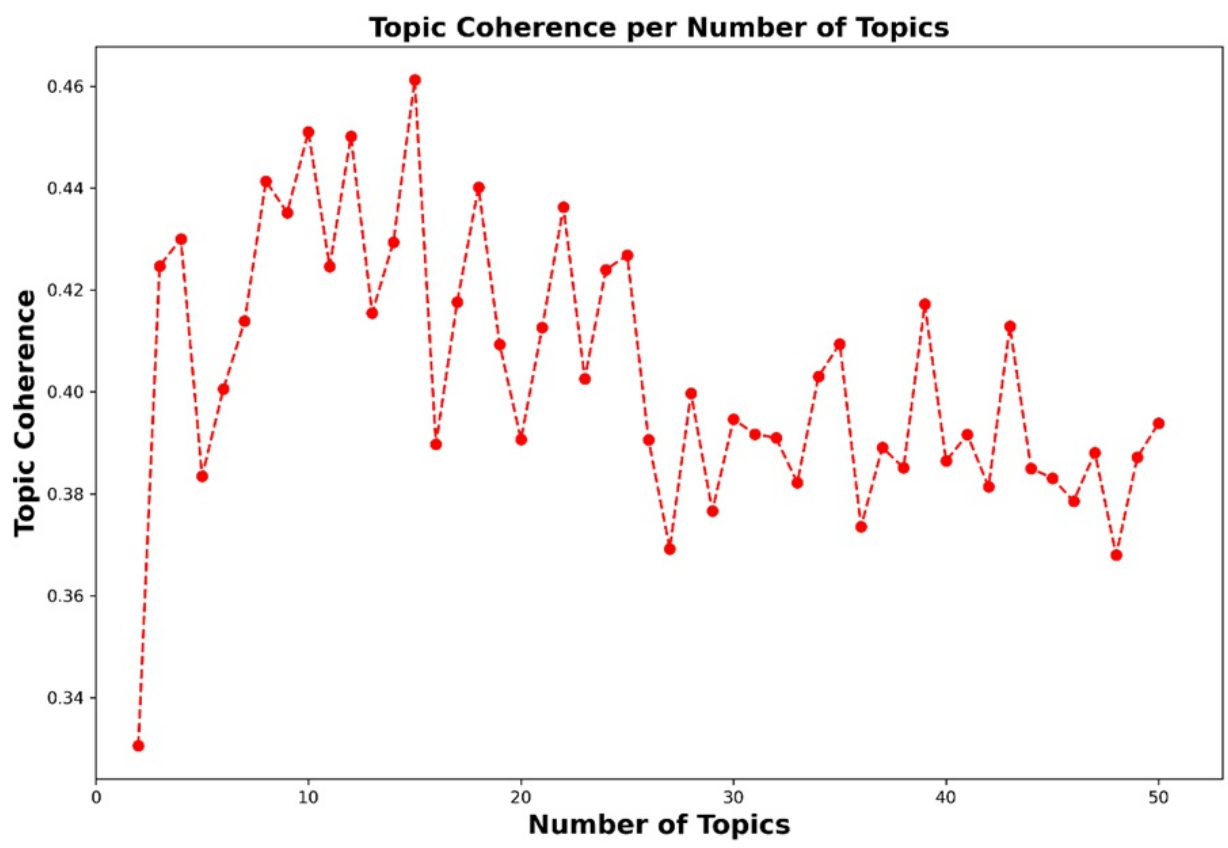

Figure 12. Topic coherence measure for $K=2-50$ 


\section{A Roadmap for Systematically Identifying Opportunities in Ecosystems Using Scientific Publications Data Behrooz Khademi, Hannele Lampela, Kosmas X. Smyrnios}
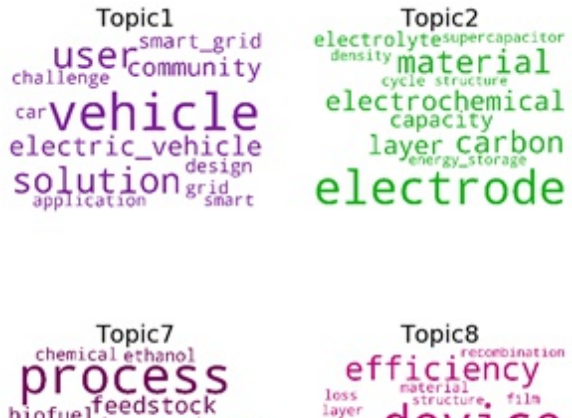
biofuel teedstock production plantbiomass product fuel biogas
Topic7
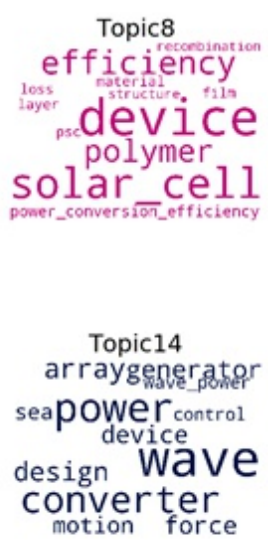

parametermodeling

\author{
Topic3
temperature \\ time chargefin \\ sensor \\ np sulfur rate
}

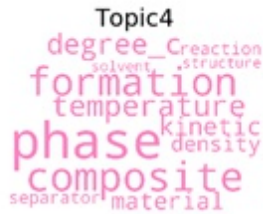

Topic9

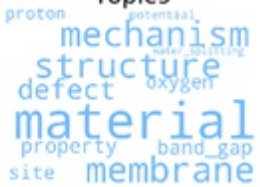

Topic15

industry marke

sustainąbility

pol icy maragement

sustainable

collector

climatewindow

SOlar ares

designmaterial

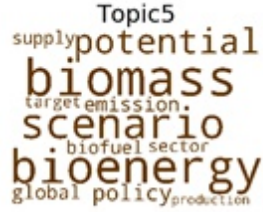

supplypotential

bioenergy biomass

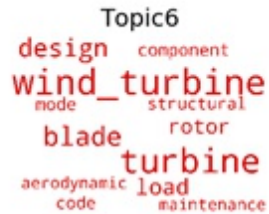

Topic12

process storage

lithium_ion_battery

dryer rate

battery

concentration
element nuty ash

Topic17

fuelcostmodel

market

price

investment

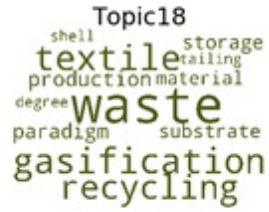

recycling

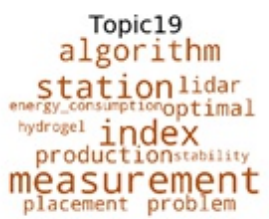

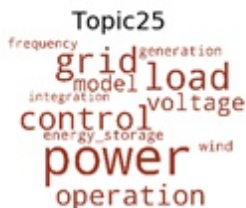

Topic31

production $\begin{gathered}\text { potential } \\ \text { ammitonia }\end{gathered}$

geothermal

nuclear_power

bicesss electricity cost

nuclear

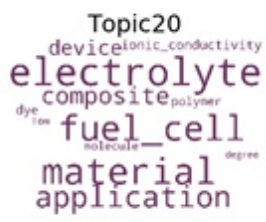

application

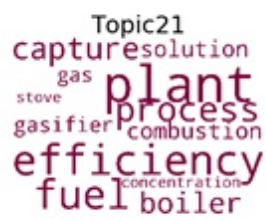

fuel boiler

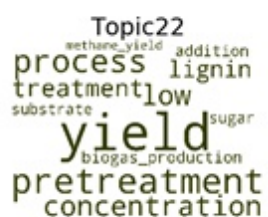

concentration

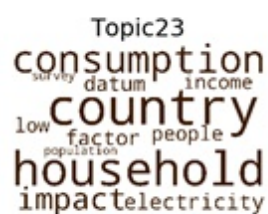

impactelectricity

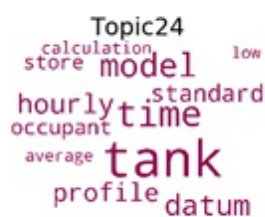

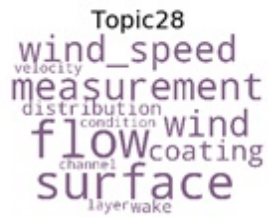

Topic34

Topic32 bearing product gearbox service region

pressure solar

${ }^{\text {isi. }}$ water

problem lifetime

hydratedesalination

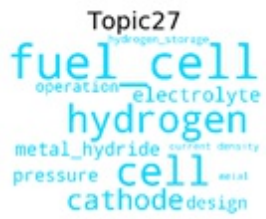

Topic33

interenumvariability

hydropower

power datum

forecast
SOi Plastic

student youghtdesign

machineschool

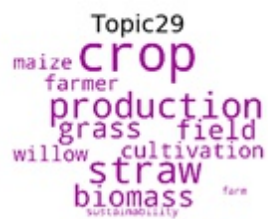

Topic35 oxide furfarbon reaction

catalyst material oxidation

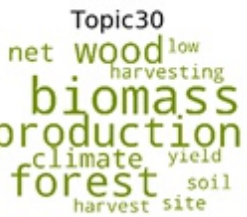

Topic36

emission urbanarea trend City dime consumption

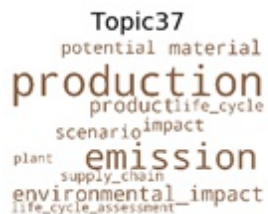

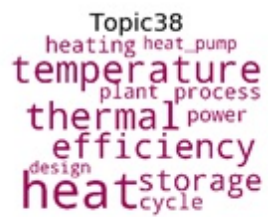

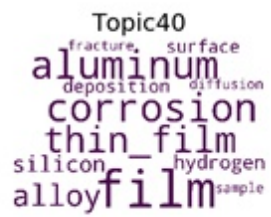

Topic41

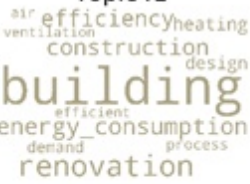

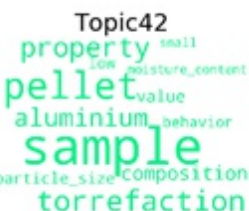

Figure 13. Word cloud for 42 topics 


\section{A Roadmap for Systematically Identifying Opportunities in Ecosystems Using Scientific Publications Data Behrooz Khademi, Hannele Lampela, Kosmas X. Smyrnios}

with noticeable financial and social value. Journal editors (across the world) can plan to publish special issues (or joint special issues with other journals), applicable to practical energy-related problems within the Nordic region. The knowledge gained about popular and impactful themes through topic modelling can provide opportunities to address grand challenges in the Nordic region.

In innovation ecosystems, federal and state-level policymakers can intervene in research and relevant industry sectors with supportive and regulatory policies to improve research departments' productivity, optimize grant size for funding agencies, systematically organize university-industry-government collaborations, and direct private sector investments towards promising research themes. In addition, governments and research councils can change the direction of job creation programmes towards pertinent areas where research can potentially create financial and social value. Managers in Nordic funding agencies can illustrate their efficiency according to grant allocations. In large funding organizations, the larger share in the number of published papers by grantees in a specific domain can be associated with more efficient research outputs by the grantees, hence giving more validity for decision-making in grant allocation. Moreover, funding agency managers can collectively define new funding programs that focus on crucial research topics in the Nordic region.

In entrepreneurial ecosystems, university graduates, academic entrepreneurs, university spin-offs, and tech start-ups can seek grants from the top funding agencies or private sector investors to servitize or productize their prototypes. In so doing, the focus on more relevant themes will increase the chance for entrepreneurs to persuade public funding agencies and private sector investors to financially support their proposed projects. Furthermore, private sector investors (business angels, venture capitalists) can make informed decisions when evaluating proposals to finance start-ups and university spin-offs, as well as to invest in collaborative research in various knowledge ecosystems.

\subsection{Methodological Novelty}

Our study's methodological relevance is based on the need for developing new methods in technology and innovation management research (Ritala, Schneider, \& Michailova, 2020), and particularly for analyzing ecosystems (Khademi, 2019, 2020), as has been accentuated recently. The proposed roadmap combines techniques in productivity measurement, networkbased clustering, and text analytics. We applied four novel techniques when devising the roadmap: 1) simultaneous application of regional, dynamic, and

Table 6. Clusters of renewable energy research in the Nordic region

\begin{tabular}{|c|c|c|c|c|}
\hline No & $\begin{array}{lr}\text { Source } & \text { of } \\
\text { renewable } & \text { energy } \\
\text { production } & \end{array}$ & $\begin{array}{l}\text { Energy storage and } \\
\text { distribution }\end{array}$ & Energy consumption & Socio-techno-economic issues \\
\hline 1 & Solar (topics 8, 40) & $\begin{array}{l}\text { Hydrogen (topics 9, 12, } \\
20,27,35,39 \text { ) }\end{array}$ & $\begin{array}{l}\text { market demand and energy } \\
\text { consumption (topic 16) }\end{array}$ & Emissions from bioenergy (topic 5) \\
\hline 2 & $\begin{array}{l}\text { Wind (topics 6, 13, } \\
28\end{array}$ & $\begin{array}{l}\text { district heating (topic } \\
\text { 38) }\end{array}$ & $\begin{array}{l}\text { electric vehicles (topics } 1 \text {, } \\
\text { 19) }\end{array}$ & Fuel price and investments (topic 17 ) \\
\hline 3 & Wave (topic 14) & $\begin{array}{l}\text { power grids and smart } \\
\text { grids (topics } 1,25 \text { ) }\end{array}$ & $\begin{array}{l}\text { Solar energy application in } \\
\text { buildings (topic 10) }\end{array}$ & $\begin{array}{l}\text { Renewable energy demand and cost } \\
\text { scenario analysis (topic } 16 \text { ) }\end{array}$ \\
\hline 4 & $\begin{array}{l}\text { Hydropower (topic } \\
\text { 33) }\end{array}$ & $\begin{array}{l}\text { supercapacitor } \\
\text { batteries (topic 2) }\end{array}$ & $\begin{array}{l}\text { Solar desalination (topic } \\
\text { 26) }\end{array}$ & $\begin{array}{l}\text { environmental life-cycle assessment } \\
\text { (topic 37) }\end{array}$ \\
\hline 5 & $\begin{array}{l}\text { Geothermal (topic } \\
\text { 31) }\end{array}$ & $\begin{array}{l}\text { Polyethylene battery } \\
\text { (topic 4) }\end{array}$ & & $\begin{array}{l}\text { energy policy and sustainable } \\
\text { transition (topic 15) }\end{array}$ \\
\hline 6 & $\begin{array}{l}\text { Biomass (topics 21, } \\
22,29,30,42 \text { ) }\end{array}$ & $\begin{array}{l}\text { Lithium-ion batteries } \\
\text { (topic } 11 \text { ) }\end{array}$ & & $\begin{array}{l}\text { renewable energy sources and energy } \\
\text { efficiency in buildings (topic } 41 \text { ) }\end{array}$ \\
\hline 7 & Biogas (topic 7) & $\begin{array}{l}\text { Thermal energy Storage } \\
\text { (topic 24) }\end{array}$ & & $\begin{array}{l}\text { Recycling and circular economy (topic } \\
\text { 18) }\end{array}$ \\
\hline 8 & Thermal (topic 3) & & & $\begin{array}{l}\text { Lifestyle issues in energy consumption } \\
\text { and environmental impact (topics } 23 \text {, } \\
36 \text { ) }\end{array}$ \\
\hline 9 & Tidal (topic 32) & & & Environmental education (topic 34) \\
\hline
\end{tabular}




\section{A Roadmap for Systematically Identifying Opportunities in Ecosystems Using Scientific Publications Data Behrooz Khademi, Hannele Lampela, Kosmas X. Smyrnios}

domain-specific analyses, which can be beneficial for mitigating boundary-related challenges in ecosystem research design (Phillips \& Ritala, 2019) by controlling for the boundaries of created scientific knowledge, 2) combining co-authorship analysis and bibliographic coupling, which is helpful for systematically identifying possible collaboration opportunities, 3) extracting insights from the metadata regarding funding agencies, which helps not only the agencies, but also governments, researchers, and practitioners, and 4) employing new techniques when identifying research themes in a geographically-bounded region, which creates value for public and private sectors for investments.

\subsection{Limitations and Potential Avenues for Future Research} Our study was subject to four limitations, which can be regarded as starting points for future research. First, our roadmap does not investigate diagnostic analytics. Although exploring causal relationships can be highly valuable for long-term predictions, the process is also highly context-specific and requires primary data collection. Second, we considered only scientific publications along with techniques of our choice to devise the roadmap, whereas other data sources and techniques could have culminated in alternate roadmaps. In the future, researchers can use other WoS metadata or sources (for example, patents and market reports) to devise new roadmaps. Third, we did not take into account the ranking of selected journals for analyzing funding agencies. Employing this strategy could have resulted in deeper knowledge about the impact of outputs per sponsor. Scholars can thus take this shortcoming into consideration for future research. Finally, it could be of interest to see the real financial and social values of the roadmap in experimental projects. For this, researchers can therefore employ the roadmap in projects and report the pros and cons of the roadmap.

In conclusion, this study proposed a novel analytical approach for identifying opportunities in ecosystems. We also showed an example of how the application of our roadmap can benefit ecosystem actors. Data analytics, as this example indicates, can therefore open up several new windows for academics, managers, and policy-makers.

\section{References}

Alexy, O., George, G., \& Salter, A.J. 2013. Cui Bono? The Selective Revealing of Knowledge and Its Implications for Innovative Activity. Academy of Management Review, 38(2): 270-291.

https://doi.org/10.5465/amr.2011.0193

Almpanopoulou, A., Ritala, P., \& Blomqvist, K. 2019. Innovation Ecosystem Emergence Barriers: Institutional Perspective. Paper presented at the The 52nd Hawaii International Conference on System Sciences. http://hdl.handle.net/10125/60070

Autio, E., Kenney, M., Mustar, P., Siegel, D., \& Wright, M. 2014. Entrepreneurial innovation: The importance of context. Research Policy, 43(7): 1097-1108. https://doi.org/10.1016/j.respol.2014.01.015

Clarysse, B., Wright, M., Bruneel, J., \& Mahajan, A. 2014. Creating value in ecosystems: Crossing the chasm between, knowledge and business ecosystems. Research Policy, 43(7): 1164-1176. https://doi.org/10.1016/j.respol.2014.04.014

Dougherty, D., \& Dunne, D.D. 2011. Organizing Ecologies of Complex Innovation. Organization Science, 22(5): 1214-1223. https://doi.org/10.1287/orsc.1100.0605

Gralka, S., Wohlrabe, K., \& Bornmann, L. 2019. How to measure research efficiency in higher education? Research grants vs. publication output. Journal of Higher Education Policy and Management, 41(3): 322341.

https:// doi.org/10.1080/1360080X.2019.1588492

Jarvenpaa, S.L., \& Välikangas, L. 2014. Opportunity Creation in Innovation Networks: Interactive Revealing Practices. California Management Review, 57(1): 67-87.

https://doi.org/10.1525/cmr.2014.57.1.67

Jarvenpaa, S.L., \& Välikangas, L. 2016. From Governance Void to Interactive Governing Behaviors in New Research Networks. Academy of Management Discoveries, 2(3): 226-246.

https://doi.org/10.5465/amd.2014.0103

Jarvi, K., Almpanopoulou, A., \& Ritala, P. 2018. Organization of knowledge ecosystems: Prefigurative and partial forms. Research Policy, 47(8): 1523-1537. https://doi.org/10.1016/j.respol.2018.05.007

Ketonen-Oksi, S., \& Valkokari, K. 2019. Innovation Ecosystems as Structures for Value Co-Creation. Technology Innovation Management Review, 9(2). http://doi.org/10.22215/timreview/1216

Khademi, B. 2019. The Ecosystem Knowledge Explorer: A Tool to Systematically Discover External Knowledge. Technology Innovation Management Review, 9(7). http://doi.org/10.22215/timreview/1253

Khademi, B. 2020. Ecosystem Value Creation and Capture: A Systematic Review of Literature and Potential Research Opportunities. Technology Innovation Management Review, 10(1). http://doi.org/10.22215/timreview/1311 


\section{A Roadmap for Systematically Identifying Opportunities in Ecosystems Using Scientific Publications Data Behrooz Khademi, Hannele Lampela, Kosmas X. Smyrnios}

Lindkvist, L. 2005. Knowledge Communities and Knowledge Collectivities: A Typology of Knowledge Work in Groups*. Journal of Management Studies, 42(6): 1189-1210.

https://doi.org/10.1111/j.1467-6486.2005.00538.x

Moore, J.F. 1993. Predators and prey: a new ecology of competition. Harv Bus Rev, 71(3): 75-86.

NEA. Focus Areas (Nordic Research and Demonstration Programme).

https://www.nordicenergy.org/about-us/focus-areas/

OECD. 2018. Gross domestic spending on R\&D. https://data.oecd.org/rd/gross-domestic-spendingon-r-d.htm

Overland, I., \& Sovacool, B.K. 2020. The misallocation of climate research funding. Energy Research \& Social Science, 62: 101349 . https://doi.org/10.1016/j.erss.2019.101349

Pellinen, A., Ritala, P., Järvi, K., \& Sainio, L.-M. 2012. Taking initiative in market creation - a business ecosystem actor perspective. International Journal of Business Environment, 5(2): 140-158. https://doi.org/10.1504/IJBE.2012.046204

Perry, N., Candlot, A., \& Schutte, C. 2010. Factors of Success Analysis and Comparison. Journal of Decision Systems, 19(1): 75-91. https://doi.org/10.3166/jds.19.75-91

Phillips, M. A., \& Ritala, P. 2019. A complex adaptive systems agenda for ecosystem research methodology. Technological Forecasting and Social Change, 148: 119739.

https://doi.org/10.1016/j.techfore.2019.119739

Pidun, U., Reeves, M., \& Schüssler, M. 2020. Why Do Most Business Ecosystems Fail?

https://www.bcg.com/en-au/publications/2020/whydo-most-business-ecosystems-fail

Ritala, P., Schneider, S., \& Michailova, S. 2020. Innovation management research methods: embracing rigor and diversity. $R \& D$ Management, 50(3): 297-308.

https://doi.org/10.1111/radm.12414

Rohrbeck, R., Hölzle, K., \& Gemünden, H.G. 2009. Opening up for competitive advantage - How Deutsche Telekom creates an open innovation ecosystem. R\&D Management, 39(4): 420-430.

https://doi.org/10.1111/j.1467-9310.2009.00568.x

Scaringella, L., \& Radziwon, A. 2017. Innovation, entrepreneurial, knowledge, and business ecosystems: Old wine in new bottles? (article in press). Technological Forecasting and Social Change. https://doi-

org.ezproxy.lib.rmit.edu.au/10.1016/j.techfore.2017.0 9.023

SCImago, n.d., SJR SCImago Journal \& Country Rank [Portal].

https://www.scimagojr.com/journalrank.php?categor $\mathrm{y}=2105$
Stam, E. 2015. Entrepreneurial Ecosystems and Regional Policy: A Sympathetic Critique. European Planning Studies, 23(9): 1759-1769.

https://doi.org/10.1080/09654313.2015.1061484

Thomas, L., \& Autio, E. 2020. Innovation Ecosystems in Management: An Organizing Typology SSRN Electronic Journal.

http://dx.doi.org/10.2139/ssrn.3476925

Valkokari, K. 2015. Business, Innovation, and Knowledge Ecosystems: How They Differ and How to Survive and Thrive within Them. Technology Innovation Management Review: 17-24.

http://doi.org/10.22215/timreview/919

Valkokari, K., Seppanen, M., Mantyla, M., \& Jylha-Ollila, S. 2017. Orchestrating Innovation Ecosystems: A Qualitative Analysis of Ecosystem Positioning Strategies. Technology Innovation Management Review, 7(3): 12-24.

http://doi.org/10.22215/timreview/1061

van Eck, N., \& Waltman, L. 2009. Software survey: VOSviewer, a computer program for bibliometric mapping. Scientometrics, 84(2): 523-538. https://doi.org/10.1007/s11192-009-0146-3

Ziegler, B. 2011. Methods for Bibliometric Analysis of Research: Renewable Energy Case Study. 


\section{A Roadmap for Systematically Identifying Opportunities in Ecosystems Using Scientific Publications Data Behrooz Khademi, Hannele Lampela, Kosmas X. Smyrnios}

\begin{abstract}
About the Authors
Behrooz Khademi is a PhD Candidate in Technology and Innovation Management at Royal Melbourne Institute of Technology (RMIT) in Melbourne, Australia. He received his BSc degree in Production and Manufacturing Engineering from the National Technical University of Ukraine in Kiev, Ukraine, and his MSc degree in Industrial Engineering and Management from Lappeenranta University of Technology in Lappeenranta, Finland. His research focuses on value creation, value capture, and knowledge management in ecosystems. He applies a variety of scientometric, patentometric, and text mining methods in his research.
\end{abstract}

Hannele Lampela (D.Sc in Tech) is a Senior Research Fellow in Industrial Engineering and Management research unit at University of Oulu, Finland. She has more than 15 years of experience in university teaching and research, with diverse topics in information and knowledge management such as networked value creation, innovation management, distributed knowledge work, competence management, inter-organizational learning, and product lifecycle information management. Her current research interests focus on information and knowledge-driven transformation in different industries, ecosystems and platforms. In addition to her teaching and research experience, Dr. Lampela has extensive project experience by being involved in several EU and nationally funded research projects.
Kosmas X. Smyrnios is an Honorary Professor of Family Business Entrepreneurship, in The School of Business and Management, The University of the South Pacific. Kosmas was a past Foundation Associate Editor of the Journal of Family Business Strategy and former Associate Editor of the Family Business Review journal, and a former Foundation Board Member of the International Family Enterprise Research Academy (IFERA). Kosmas has undertaken a number of research consultancy projects for prominent multinational corporations including AXA, the Commonwealth Bank, MGi Australasia, Price Waterhouse Coopers, BDO Chartered Accountants, and Family Business Australia. Professor Smyrnios is also frequently called upon to provide expert media commentary on pertinent matters relating to family business and entrepreneurship. Professor Smyrnios has secured over $\$ 1.5 \mathrm{~m}$ in competitive and industry research funding and has supervised $30 \mathrm{PhD}$ candidates to successful completion, the projects of which include family business best practice, organizational resilience, strategic and marketing capabilities, information systems capabilities, accounting and strategic management education, business coaching, and the biological and genetic basis of narcissism.

Citation: Khademi, B., Lampela, H., Smyrnios, K.X. 2020. A Roadmap for Systematically Identifying Opportunities in Ecosystems Using Scientific Publications. Technology Innovation Management Review, 11(1): 3455. http://doi.org/10.22215/timreview/1415

Keywords: Ecosystem, knowledge, opportunity, roadmap, scientometrics, text mining 